SONE DISTINCTTONS IN OUR CULTIVATISD BARTIEYS WTTH RIPIRETTCE TO THETR UST IN

PLANY BREIEDTNG.

\author{
A thesis submitted to the Paculty \\ of the Graduate School \\ of the University of Minnesota.
}

by

Harry V. Harlan

in partial iullilment of the requirements for the degree of Doctor of Science. 
TABT,E OF CONTEINTS.

Introduction ....................... I

Review of Literature .................. 6 B

Rate of Development ................. 7

Berly Dovelopmant .................

Iithergence of the Awns .............. 11

Date of Ripening .................... 14

Comprrative Rates of Development ........ Is

Variations in the Culm ................... 18

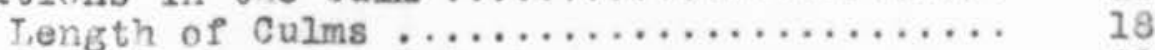

Dlameter of the culm ................. 20

Thickness of Walls of Culm ........... 21

The Bxsertion of the spike $\ldots \ldots \ldots \ldots \ldots \ldots .22$

Number of Nodes per cuim .............. 23

Number of Culms per Plant ............ 23

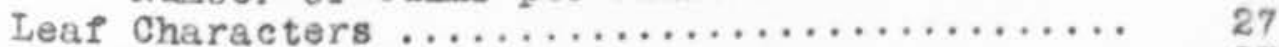

Color of Teaves ..................... 27

Width and Length of Leaves ........... 27

Number of Leaves ..................... 31

The Denstty of the Spike ................ 33

Fert1lity ............................ 45

The Rapty, or Outer, Glumes $\ldots \ldots \ldots \ldots \ldots \cdots \cdots \cdots$

The Plowering Glumes .................... 51

Awns ............................. 51

The Base of the Flowering olume ....... 56

The Adherence of the Flovering Glumes to tha pericarp ................... 57

The svalof characters $\ldots \ldots \ldots \ldots \ldots \ldots \ldots \ldots \ldots . \quad 58$

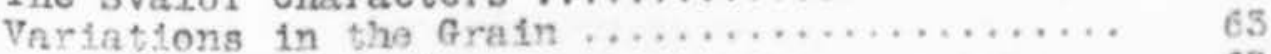

Shape of Grain ...................... 63

The Dimensions of the Grain ........... 64

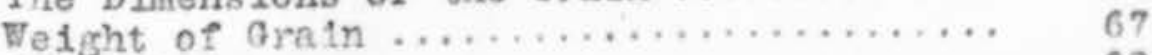

Composition ........................ 68

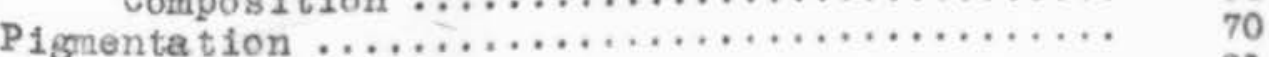

Stmmary

Bibliography ........................ 88 
IIST OF PTGURES.

Fig. 1. The Occurrence of the Second, Third and Pourth

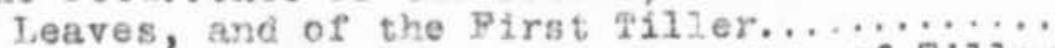
PiE. 2. Varietal Differences in the Rapidity of TillerF1f. 3. The Average Date of the Production of the Second and Third Leaves, and the Pirst Tiller..

Fif. L. Surmary of the Jmergence of the Awns ........ Pig. 5. The Erfect of Season upon the Relative Date of

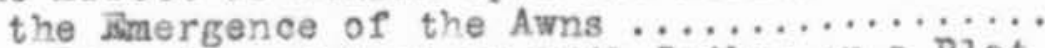

P1g. 6. The Ripening of Bach of 1541 Spikes on a Plot

P1g. 7. The Date of the Production of the Second, Third and Pourth Leaves, the plrst T112er, the Fmergence of the Awms, and the Day of Ripen-

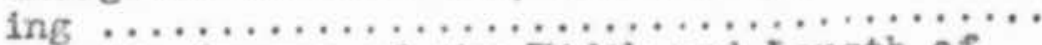

F1g. B. Composite Curves of the $\mathbb{V} 1 d$ th and Length of Jeaves $\ldots \ldots \ldots \ldots \ldots \ldots \ldots \ldots \ldots \ldots \ldots \ldots \ldots \ldots \ldots$. $\ldots \ldots$. F16. 9. The Density of One Hundred Spikes of Manchuria

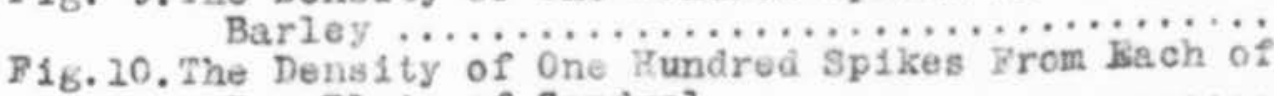

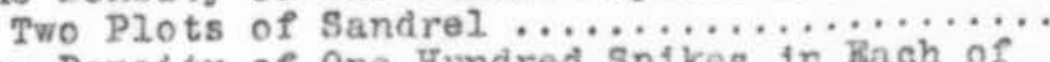
P1g. 21. The Density of One Hundred Spikes in Rach of Two Selections of Kanchuria $\ldots \ldots \ldots \ldots \ldots \ldots$ Pig. 12. The Average Dens1ty and the Date of Imergence

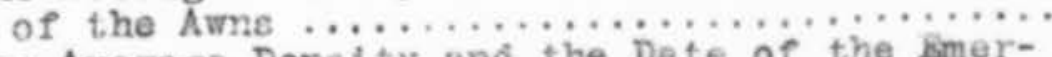
P1g. 13. The Average Density and the Date of the Imer-

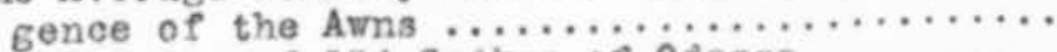
F1E. 24. The Density of $134 \mathrm{splkes}$ of Odessa ......... Fig.15. The Average Density of $\mathrm{S} i \mathrm{x}$ Selections of Barley

\section{LIST OF TABLES.}

Table I. The relation of Boographlal location to length of culm......................

Table TT. The effect of interval on the production of
culms in selections of Smyrne and Man-

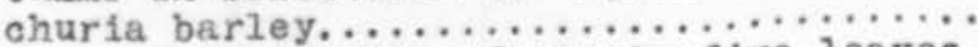

Table IIT Average measurements of twenty-five leaves.

Table TV.w1dth and length of leaves................

Table V. Distribution into their various densities of 100 spikes from each of 59 plots........

Table VI. The effect of climate upon the grain...... 
PTAATT BREGEDTNG.

INTRODUCT TON.

When the writer began active operationsin barley in 1909

breeding, the intelligent selection of mother plants was

found to be very difficult because of the lack of sufficient

information to enable him to recognize and interpret minor

variations. Juropean breeders had subjected the taxonomic

details to a most exacting scrutiny, but their results were

not immediately useful. It was necessary to confim the

Luropean findings, for a character found stable there could not be considered stable under the widely varying climatic conditions of America until it had been so proven. Again, the European authorities were far from united. There was 
not even a broad taxonomic character whose stability had not been questioned at some time or other, and often by the highest authorities in barley classification. Moreover, even if the groundwork could have been adopted entire, the more or less established taxonomic characters are only the beginning of the problem. Breeding must take note of characters that are trivial in taxonomy. The intangible must be analyzed and made to serve as well as the tangible. Even the very plausible 1 dea of adopting European methods and importing improved Iuropean stocks, was only partially successful. Conditions in America differ in one vital essential from conditions in Burope. On the Continent and in Great Britain barley has been cultivated for centuries, and 1s therefore practically indigenous. Bach geographical locality has, through long periods of time, been provided by natural selection and acclimatization with superior native races. Breeding, under such conditions is largely concerned 
with the improvement of these existing stocks, with small

likelihood of any importation proving to be a serious competitor.

In America there are no native stocks. The grain producing areas are relatively new. The varieties peculiar to a section are usually the result of chance importations. Breeding material from foreign sources is as likely to contain desirable types as is that already at hand. In this investigation, in order to secure the proper basis upon which to conduct breeding work, stocks were assembled, not only from local sources, but from all over the world. Vany distinct strains were isolated from each stock, for both the local varieties and the forelgn importations were usually either races that had not been purified, or that had become mixed after purification. The isolation was accomplished by head and plant selections which, when 
grown in pedigree rows, formed a surprisingly large collection.

When to these were added a st1ll greater number from the progeny of hybrids, the problem became one of elimination. The plant selections, from their very nature, were made more or less arbitrarily and hundreds of these forms were necessarily duplicates. These duplicates, especlally as long as they were not so recognized, were a drain upon the breeder, and it was soon realized that the efficiency of a nursery was measured, not by the number of stocks it carried, but by the number it eliminated.

It was to better accomplish this reduction that the character studies were made. The distinctions found were of two classes; morphological and phydological. The morphological variations were in the broader divisions of taxonomic value, and many of them were practically invariable. The physiological characters were, from their nature, more 
difficult to appraise. They were found to possess not only more widely rluctuating limits, but the limits often overlapped and at times the characters became inseparable. In physiological characters a farther distinction was made between permanent and place varlations. Some separations were so wide that they never beame confusing, while others became evident only when grown under certain conditions of soll and climate. Such distinctions are worthless as systematic features, but have proven very valuable as indications of Individual qualities in breeding. IBven the lack of stability in a character does not destroy 1ts usefulness, as the tendency of a strain to behave in a certain manner under certain conditions may mark an inherent difference. It is realized that distinctions of this kind are only a part of plant breeding, and it is not thought that that part is in any great measure solved, but in this 
paper are given a few of the observations that have been found useful in barley breeding, and with them many that have been found useless. The data upon which the conclusions are based consist of some 200,000 recorded observations, extending over a period of five seasons and embracing exper1ments in St. Paul, Minnesota; Villiston and Dickinson, North Dakota; H1ghmore, South Dakota; Mocoasin, Montana; Aberdeen and Gooding, Idaho; and Chico, Callfornla. Of the work done at these points, that at St. Paul, Minnesota, was the more extensive and was carried on in co-operation with the State Experiment Station. 
REVTEW OF LITERATURE.

Although the literature on barley is perhaps

more extensive than on any other cereal crop, the publica-

tions bearing directly upon this paper are comparatively

few. The great mass of the Iuropean publications, especially

the German, have to do with the malting quality of barley.

They are concerned mostly with its chemical constituents,

the effect of soil, climate and culture upon the nature and

composition of the grain, and the behavior of the converting

enzymes in grains of different character. The same is true

of the morphology of the grain, and even many of the publica-

tions treating directly with barley breeding have little

bearing upon the present discussion, as they are often concerned only with the correlation of characters, or with the behavior of hybrids.

It is only the papers dealing with the systematic

features of barley, and experiments such as those of the 


\section{$-2-$}

Svalof Station, which have had for their end the isolation of plant variants that are of particular pertinence.

The PIrst comprehensive systematic work was that of Koernicke, in his "Arten und Barietaten des Getreides". He dasoribes forty-four botanical forms of barley, using spikelet fertility, solor, nature of the awn and glume, and the adherence or non-adherence of the palea. His groups w112 undoubtedly form the bases of all future classifications. The classification of vo $\frac{20}{88}$ is important largely because he based a part of it upon the extent of overpapping of the grains, thus forecasting in an indefinite wagy the use of density. Atterber $\frac{1}{\mathfrak{B}}$ made use of the bristle and nerve characters discovered by Neergaard, mentioned below, and subdivided the previous groups until he had 188 named botanical varieties. Beave $\frac{2}{n}$, by a rearrangement and compilation of previous classifications, and by growing and describing 
a large number of hybrids of Karl Hansen, Koernicke, and others, gave a very clear conception of the entire species. His work is perhaps most valueble in the placing of the Abysinian forms with abortive lateral florets in a group by themselves. He does not make use of the finer subdivisions employed by Atterberg. RegeI, on the contrary, carries the sub-division still farther and uses twisting of the spike, earliness, and latenesa of the varlety, in his separations. The last, a purely physlological phase, he employes in named botanical forms.

A review of the work of the Svalof station is especially valuable in this connection, both because of the fact that a large part of their effort has been along the same 2ine, and because in many instances this investigation has mereiy attemptod to discover whether results obtained by them were sustained under the great varietion of 
American climate. In barley their greatest achievement was the discovery of two graing characters which, by various combinations, gave four separations under each previous group.

They found that the rachilla in some barleys was covered with long straight hairs, and in others with short curly ones: that the inner pair of dorsal nerves sometimes bore teeth, and were sometimes smooth. The stability of these characters was questioned by Broil $\frac{9}{1}$, who claimed to have erequently observed one form in the progeny of another. Tschernak, Blaringhem and others, have supported the Svalor Station at least as far as the basal bristle is concerned. Although not to be compared $w$ ith this discovery in importance, the Svalor station has made many other studies. At one time they had developed a very elaborate system of measurements with many ingenious mechanical devices. They 
have, unfortunately, made no specifle, comprehensive, publication of their negative results, but according to Kewmann and others, they have abandoned many of the measurements that were formerly made. of those retained, the most important from the standpoint of this paper is that of density. In the early history of the station two or three varieties were obtained by the "elete" method. They chose an arbitrary density and made mass selections of spikes conforming to that measurement. Later thez used density as a means of valuing head measurements; as a long head, if loose, might contain no more grains than a short one if conpact. They finally employed it in varietal description. Blaringhem, who has followed the Svalof Station quite closely, used density as an indication of purity, and to reveal the effect of climate.

The morphological characters of the seed-coat and the grain have been treated by Kudel $\frac{14}{k a}$ and Johannsen, 
but there is no suggestion of usable varietal differences. The composition of the grain has been studied by a few American, and a large number of European, scientists. Le cle $\frac{15}{r c}$ and wahl, who have made the most comprehensive of the American studies, have clearly demonstrated that composition is of slight use as a varietal character, for while there are differences, the effect of location and season is many times greater than that of sort.

Color in barley has been employed by all systematists, but has received very 21 ttle analytical attention. Brown has a note in the color in coerulescens, and numerous authors have discussed the occurrence of pigments in other plants. A recent article by Wheldale treats of the chemical nature of anthocyanin and traces 1 ts origin from a glucoside. 


\section{BIBIJTOGRAPHY.}

1. Atterberg, A. Die Varietaten und Formen âer Gerste. Journal fur Landwirtschaft. 1899. Vol. 47 pp. 1-44

2. Beaven, E. S. Varieties of Barley. Journal of the Federated Institutes of Brewing. Vol. VIIT, No. 5, 1902.

3. Biffin, R. H. The Tnheritance of Sterility in the Barieys. Journal of Agricultural Science. Vol. 1.

4. Blaringhem, I. I'Amelioration des Crus d'Orges. Paris, 1910.

5. Le Laboratoire d'Hssais de Semences de Svalof. Bületin du Yuseum d'Histolre Natunelle. गo.7, pp. 514-520. 1904.

6. La notion d'Espece. Revue des Tdees. 1905.

7. La variation des formes vegetales. Revue Generale de Botanique. Vol. XX, pp. 49-66.

8. Brenchley, w. IS. The Development of the Barley Grain. Annals of Botany. July, 1912.

9. Brolli, J. Das Gerstenkorn im Bilde. Stuttgart, 1908.

10. Brown, A. J. Note on Green-skinned Iight Barley. Journal of Federated Institutes of Brewing. pp.480-483 1900 .

11. Fruwirth, c. Dis Zuchtung der landwirtschartilehen Kulturprlanzen. Berlin, 1910.

2. Johannsen, w. Om Frohviden og dens Udvikling hos ByE. Resume du Compte Rendu du Laborato1re de Carlesberg. 1884. 
13. Koernicke, $\not$. Die Arten und Varietaten des Getreides. Handbuch des Getreldebaues. Vol.1, Bonn, 1885.

14. Kudelka, F. Ueber die Entwickelung und den bau der Frucht und Samenschale unserer Cerealien. Landwirthschaftliche Jahrbucher. Vol. 4, pp. 461-473, 1875.

15. Le Clerc, J. A. and Wahl, R. Chemical Studies of American Barleys and Yalts. United States Department of Agriculture, Bureau of Chemistry, Bulletin 124.

16. Newman, I. H. Plant Breoding in Scandinavia. Ottawa, 1912.

17. Regel, R. Les Orges Cultivees. Milan, 1906. Discussion of the Porms of Wheat, Barley, and
18. - Other plants. Bureau of Applied Botany. 1910.

19. Tedin, $\pi$. Ueber die Kerkmale der Zweizeiligen Gerste, Irhe Konstanz und Irhen Systematischen Werth. Sonderabdruck Deutsche Landwirtschaftliche Press. p. 5, 1908.

20. Voss, A. Versuch einer neven systematik der Saatgerste. Journal fur Landwirtschaft. 1885.

21. von Tschermak, E. Die Zuchtung der Landwirtschaftlichen Kulturpelanzen. Berlin, 1910.

22. Wheldale, $\mathrm{M}$. On the Formation of Anthocyanin. Journal of Genet1es. Vol. 1, p. 133-158, 1910-11. 
THE RATE OF DEVETOPIOSTI.

The rate of development, as with all physiological

characters, is subject to considerable eluctuation within

the strain. The distinctions are naturally much less abso-

Iute than those founded upon morphologleal characters. They

have, however, this advantage, they permit a greater number

of separations. A plant structure usually has but two

phases. It exists, or it does not exist. With physiolog-

1 cal characters this is not the case. The length of time

required for one variety to mature may differ three days

from a secona, or 1t may differ three weeks.

From the standpoint of observation, the develop-

ment of the plant 1s divided into threa periods: the early

development from germination to the time of Jointing, the

period of heading, and the epoch of maturity.

\section{Barly Development.}

For sometime the writer has maintained that the 
stage of development at which selections of barley are most easily told apart, is during the early growth. This period seems to have been neglected by plant breeders. There are few records of notes taken during this time and even those who have known the cereal crops the best, have based their selections at this period on an intangible something that enabled them to single out any new variatio $\mathrm{n}$. During the sumer of 1913, an attempt was made to analyze the "intangible" with most encouraging results. Besides careful observations on several hundred selections, 1400 plants were chosen in the nursery, and 1700 in drill rows, upon which exact record was kept. One hundred plants were used in each variety. The data included the day upon which each of the 3100 plants produced its second, third, and fourth leaves, and its first tiller. The optically plausible became mathematically evident, and it was soon seen that, aside from the leaf character, there was ample 
justification for the separations made on appearance during the early stages of growth. As will be sean in $\not 1 g . x$, the selections rush through the early stages at an astonishing rate. A cantganer only two, or even one, day behind a second may be in an entirely different stage of deve?opment and therefore present an appearanco which in no way rosambles the firat. Yet the tro barleys mey be elosely related 3trains and inseparable, or seperated with diffienlty, at maturity. The typical curves of the production of the ascond, third, and sourth leaves are always very sharp. In yig. I the eurve of tillering is more flat than is usualiy the anse. The fint fer of the third zaves anerge about the time of the appearance of the last of the second. The fourth lear is prodused in about the same relation to the third, but perhaps a little earlier. The first t1llers are usually sinultaneous with the pourth leaves, though in some varieties they appear earlier. The tillering in most varieties is 
not completed as rapidiy as is the production of the fourth lear, and it is deterred by disease much more than is the leaf.

Besides the difference in dates, there is a dif-

ference in method of production. In some varieties the curve of all stages is very acute and the stage is completed in a few days. In others $1 \mathrm{t}$ is more obtuse and the time For completion extended. Fig. 2 shows the relative rapidity of stooling in two selections, the one of the first type and the other of the second.

Differences are revealed in two ways by a comparison of the behavior of strains. There is an actual difference of date in any stage, and still more important, a relative difference between various stages. This is shown to some degree in $\mathrm{Big} .3$, and to a still greater degree in Fig. 7, which will be discussed later. Big. 3 shows the 
date upon which the greatest number of plants in seventeen selections, sown in drill rows, reached the three stages of development. It $¥ 111$ be not1ced that the average date of the occurrence of the second leat varied over scarcely more than two days, while the third extends over I1ve days, and the production of tillers over ten days. No. 550, for instance, produces the third leaf four days after the second, while No. 556 requires enother day. Yet No. 556 requires but six addstional days to throw off tillers, while No. 550 requíres eleven.

$$
\text { Himergence of the Beard. }
$$

The time of heading is a general agronomic note, and there is no doubt but that an observation of this period is of greet value in plant breeding. Distinctions at this time should be easily made, and should be more reliable than those at any later dete. The interval between seloctions is 
greater than in the earlier stages, and the effect of season is not apparent in abnormal hastening of development, as it is later in ripening. In any climate most barleys develop in a fairly nornal manner unt1l elowering time. The time of heading, for these reasons, should be of great use. It has, however, one disadvantage. It is an extromeIy difficult note to secure, and hence inaccurate. Barleys differ very much in their manner of heading. Some are exserted rapidly and completely, others slowly and only partially. The observer has not only the difficulty of malntaining an arbitrary mental standard, but is confronted by numerous exceptions that never conform to any standard. In a study of this difficulty, it was noticed that fust previous to heading, the tips of the avns, in all ewned varieties, projected from the boot of all plants in the selection with suggestive uniformity. The date of the 
emergence of the ams was substituted for the date of heading with excellent results. The personal error was irmediately removed, and as the facts could be gathered at a. Glance, the note taking was greatly accelersted. The change made a valuable plant bresding observation out of a dublous agronomis note.

Analyzed, the date of umorgence rakes almost as sharp a curve as the earlier observations. Vig. 4 shows the curve of 13,103 plants, a surmary of the observations upon a large number of selections. It will be notioed that nearly two-thirds of the plants pass through this stage In two days. A difference of a single day serves to change the appearance of a whole centgener, and strains that are three days apart are unbelievably dissimilar whon viewed at this time.

This note was used upon a large number of selections for three years to test the transmissions of slight 
viriations in earliness and lateness. The evidence semed ali In favor of acorediting this character a horitable quality equal to that of most plant charscters. The data are too cumbersome to inclucie entire, but a rendom selection of strains of one general type is given in 7.5 .5 . The veriatlons are, on the whole, perallel, especially when 1 t is remombered thet the contgeners were often separsted by considerable intervals, ellowing varietions in soil and noisture. The exceptions are fully as Iikely to represent differences in the character of the strains, causing then to respond differently to different seasons, as they are to question the value of the note.

\section{Date of Ripening.}

The date of ripening is a note miversaliy taken.

Mnile lass dependable than the amergence of the beerds, it is a very useful observation. Fithin a strain the plants 
mature quite uniformly. In order to detarmine the amount of such variation, the exact date of maturity of each spike upon a plot of Manchurta barley, was recorded. The splkes were considered ripe when the last traces of Ereen disappeared from the elunes. In order to avold confusion, they wore harvested as fast as they ripened. The result is shown in Pig. 6. The curve is very sherp, alnost half the product of the plot maturing unon the same day. The weakness of the note is in the abnornal ripentug of varieties. At rinnesote the observation is quite dependable in Nenchuria forms, but is likely to be much less so in the two-row varieties. Some of the latter mature in a normal manner, while others, espectally the later ones, half ripen and half die. Also a rain et this period hes nuch more influence in the development than at other times in the life of the plant. 
Comparative Rates of Development.

Although separations can be made by a study of any one of these stages, it is only when the entire seasonal histories of the selections are compared, that the full variation is apparent. Pig. 7 shows the development of fourteen strains from the production of the second leaf unt1l maturity. Each stage was obtained by actual count of all the normal plants in each centgener, usually between ninety and one hundred.

The relation of the earlier stages has already been commented upon. It $w 111$ be noticed that usually the t11lers are produced after the fourth leaves. In Nos. 34, 13 , and 24 this is not the ease, and these three selections are definitely distinct from the other eleven by this different hablt of tillering. Nos. 21 and 57 are parallel in the earlier stages, but are widely separated in the emergence of the beard. No. 29 is one of the earliest of all 
the selections to throw off the second leaf, and yet is among the very latest in maturity. Indeed, there is some peculfarity about each and every one of the fourteen, when all stages are considered. 
VARTATIONS IN THE CUIM.

The culm varies in length, diameter, thickness

of walls, exsertion of spike, number of nodes, and number

of culms per plant.

Length of culms.

The height of the plant is a note universally

taken on all experimental farms, and at any chosen station some varieties are always tall and others always short.

This distinction is sufficient to prove a difference between such varieties

the two, and as such it is a useful observation in breeding. It is, however, merely a proof that a difference exists and is not necessarily a difference in 1 tself. There is a physiological adaptation of varieties to certain places and it may express itself in helght.

In 1911 thirteen pedigree selections, representing nine minor groups of barley, were chosen from the nursery 
stock and planted at four widely separated points. At maturity the length of culm was carefully noted. The inPluence of climate and soll was surprisingly great. As will be seen in Table $I$, there is a marked regional response.

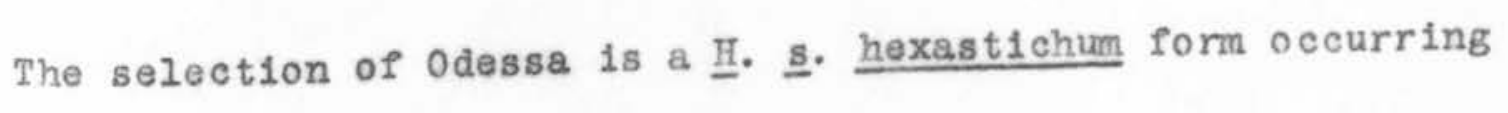
in the commercial variety Odessa. In Minnesota it is short and unpromising. In California it is $\not$ little better. In the north Rocky Mountain and plains area, however, it displays an unexpected vigor and is very tall. The Abysinian varieties grow well in California, but are short elsewhere.

The great variation evidenced by these few selections is sufficient to show that the length of culm can not be of much taxonomic value. There are varieties that are persistently below average height, and others that are as persistently above average; but beyond that it is difficult 
to make an unqualified statement. Locally this measurement is of more significance and can often be used to advantage in the study of nursery selections. The differences 1t reveals are important in breeding, no matter to what cause they may be due.

\section{Diameter of the Culm.}

Measurements have not been found very useful

in revealing small differences in the diameter of the culm. The experimental error is large, due to the fact that the diameter varies on the same plant wh the culm selected, on the same culm with the internode chosen, and on the same internode with the distance from the node. A part of this variation was avoided by measuring the greatest diameter of the first elongated internode, but even then the results were unsatisfactory. There are varietal differences, but they must be great enough to be seen optically before the 
error of measurement is reduced to the point where it becomes negligible. As a group, the nutans has smaller culms than has the Manchuria, but among the Nanchuria strains there is 11ttle difference. Only once has this character been used in these investigations to isolate a type. This type has proven to be stable and perhaps the effort of measuring hundreds of selections is rewarded by the one strain obtained, as it is very promising.

\section{Thickness of Walls of Culm.}

A large number of determinations were made of the thickness of the walls of the culm with even less satisfaction than upon the diameter. Measurements Piner than one-tenth of a millimeter are impractical owing to the variation within the plant and eulm. This does not give range enough to disperse the varieties. For instance, of 242 selections of six-row barley, the culms of 153 measured 
five-tenths millimeters in thickness and only thirty-three fell more than one-tenth millimeter from this flgure.

The Exsertion of the Spike.

The exsertion of the spike is closely related to

the length of culm because 1 t depends upon the elongation

of the peduncle. Some barleys clear the boot much more completely than do others. That this is a true varietal characteristic is shown by the number of varieties in which 1t has been described. The Prinsess in Sweden is often included at the base. The same is true of this variety in Minnesota or California. The Smyrna seldom clears the boot completely in more than one or two culms on each plant. An interesting fact was noted in this variety with reference to location. In 1 innesota half the head often remains in the boot. The same is true over the whole of the plains area. In Calffornia, however, 
the heads are completely exserted. The necks are 3 till short as compared with most varieties, but the exsertion is perfect. Like other physiological characters, the exsertion of the spike is variable, but its range of variation is sufficiently limited to occasionaliy determine a variety. That it is not more often useful is due to the fact that almost all barleys are of the type in which the splke is completely exserted.

$$
\text { Number of Hodes per Culm. }
$$

The number of nodes to the culm is naturally

identical with the number of leaves to the culm and is

discussed under that heading.

\section{Culms per Plant.}

The number of culms per plant seems to be a varietal character, but one which is so dominated by en- 
viroment as to make it impossible to determine when it

Is given true expression. It is probable that ell students

of the cereals have gone through the same process of dimin-

ishing confidence to final doubt, as to the utility of

this factor. In this investigation the number of tillers

was recorded on over twenty thousand plants without being

able to discover a method of using such information for

minor distinctions, as was found, for instance, w1th the

tirne and method of tillering. The broad groups vary as

groups in this character and occasionally a variety dev1-

ates sufficiently from 1ts group to become distinct, but

the mass 1s, for the most part, inseparable.

Two causes of variation were studied in detall;

viz., Interval and geographical location. At Minnesota

a selection of Sinyrna, a heavy tillering variety of a tworowed group, and a light tillering selection of Uanchuria 
of the six-rowed group, were plented at three different intervals. As will be seen in Table II the varieties remained distinct, but as the interval decreased, the difference of over three culms per plant in favor of Smyrna, rapidly dvindled to one. Types falling between these extremes were inseparable at the lesser interval. It will also be noticed that the varieties differ in the interval at which they seem to make complete use of the soll. An increase in number of plants in the Manchuria,beyond the four by four planting, does not inerease the number of tillers on the unit area, while for Smyrna the limit is not yet raached.

The response to geographical location is a disturbance sufficient to vitiate all close distinction. Iven the groups are often reversed. Bor instance, when sumarized, a large nuber of selections of six-rowed barley 
at 3 t. Paul, rinnosota, averaged 2.6 culms per plant, while at Chico, Californta, the samo selections averaged but 1.5 . The two-row group, on the contrary, averaged but 4.2 et St. Paul, whlle at chico they everaged 5.8. Smyrna, however, stood near the top in both places, showing that in extrome cases the effect of enviroment does not conceal the character. 


\section{IZAP CHARAOTERS.}

The leaves of mature berley plants present

quite a variety of aspects, but these are, as a whole, hard to record. Kost of them are mess effocts and hance treacherous because of the optical ifferences due to the angle of observation with reference to the light. This investigation is concerned with four points of variance: color, width, length, and number of leaves.

$$
\text { Color of Leaves. }
$$

A very ensual observation shows a considerable iffierence in the color of leaves, but there are so many difficulties in their valuation that the writer is unprepared to discuss their separation at this time.

Width and Length of Leaves. Any study of leaf dimensions must be statistical 
and therefore difficult to report briefly. Tho obstacles

to the use of such measurements are two. The leaf varios Wth 1 ts nourishont and with 1 ts exposure, and is often damaged by the wind. In a study of mature plants, the second lea? from the top being used In e.l工 cases, the normal yerliction was pound to be considerable. For instance, at the same place in the same season the leaves of border plants were fron one to two millimeters greater in width than those from the interior of the plot, and the length of the leaves of such plants was from one to three centimeters greater . In Prinsess, one of the least variable varieties, the average size of the leaves of the border plants was $13.7 \mathrm{~mm}$. by $24 \mathrm{~cm}$, and of the interior plants 12. $7 \mathrm{~mm}$. by $23 \mathrm{~cm}$.

To be reasible in breeding, a note must be reasonably easy to secure. To test the usefulness of this 
character, the first twenty-ifve of the hundred measurements were listed, as in Table III. With width of leap the experimental error is small, as width can be determined quite accurately, and the broadest part of the leaf 18 seldom damaged. If the figures then are conclusive mathematically, the method is practical. The probable error in the twenty-five measurements of Prinsess is \pm 1.2 . It thus falls to separate this variety dependably from Kitzing and Proskowetz, 1ts nearest relatives, or from the selection of deficiens, or Odessa. Bormthe rest, however, the separation is clear enough to be signifioant. With the two selections of oderbrucker, the separation is sufficient to establish a difference. In this case the two are closely related and the note becomes serviceable. As a rule the width of leaf is seldom surficient basis for separation in closely related strains. Fortunately such differences are 
seldom uneccompanied by other points of variance, and it

is often the sum of several differences that mark individual sorts.

In length of leaf the method is much less

promising. Not only is the probable error greater, but

the measurement is unsatisfactory. The leaves become so broken by whipping in the wind that specimens which are entire at the tip are seldom found. An effort was made to overcome this difficulty by choosing an earlier stage the better protected

of development and thus utilizing leaves nearer the ground. Although the extreme tendencies ware not jet developed, the second leaf from the seedling was found to offer fewer experimental difficulties. Such leaves were entire and the length measurements were accurate, but even then the widh wes much less variable than the length. All measurements of one hundred leaves of a strain showed a sharp curve In width, but a plat one in length, the latter sometimes 
having two sumits. Composite curvas are shown in P1g. 8. The summary of 316 pedigree selections in

Table IV shows that the comnon systemat10 groups based upon spike characters, are correlated in the nature of their leaf growth.

Number of Leaves.

The number of leaves, excluding of course those formed before the appearance of the shoots, 1s the same note as the number of elongated internodes in the culm. The number of leaves above the basal rosette is a variable, but at the save time a rarely useful, distinetion in breed1ng. Strains may be found which are vary different, but usually they are not closely related. Thus in Hannchen the number often drops to three and seldom goes above five. In a selection of $\underline{\text { H. }}$. hexastichum the number rarely falls as low as five and is usually $s i x$ or seven. But this dis- 
tinction is not necessary to separate these forms. In all of several hundred Manchuria selections, the number of leaves per culm fell upon elther four or five, Blving no opportunity for separation. 
TTE DENSTTY OP THE SPIKE.

The writer is inclined to place even moro importance upon the density of the spike than has been the tendency of many barley breeders. Aside from 1ts finer distinctions, to the writer's mind, some of the effects attributed to other characters are in reality due to the length of the internode of the rachis. Most investigstors have attributed the difference between 포 s. vulpare (tetrastichum) and ㅍ. s. hexast1chum to a difference in fertility. They have considered that in $\mathrm{H}$. S. vulgare the side floress are more reduced than in H. s. hexast1chum. Th1s supposit1on is not borne out in fact. In the H. 8 . hexastichum the central row is as favorad in nutition as it is in the H. 8. vulgare. Th1s is easily demonstrated by weighing grains from side and central spikelets. In the H. s. vulgare, the lateral grains compared with the central ones are actu- 
ally greater in relative weight than is the case in the H. s. hexast1chum.

Differences, other than density, are 11 kely to

be aue to the nature of the attachment of the lateral splkeIets. Systemat1sts describe the barley spikelots as sessile. This is true in most cases, but approaches an exception in the H. B. hexast1chum. In this group the central spikelets are sessile as usual, but the lateral ones elther possess an elongation of the base of the flowering glumes, or else are pedicellate. Among barleys collected by the writer, is a Greek form in which the lateral spikelets are elevated upon a pedicel that is over one-half as long as the length of the rachis node 1 tsele. This pedicel is jointed both at 1 ts attachment to the rachis and at its attaclment to the floret. It is the longer attachment of the lateral spikelets that allows the characteristic 
star-shaped arrangement of H. S. pyramidatum. Density is, however, a parallel factor. The compactness of the spike forces the grains to assume certain relations. Both in H. S. hexastichum and H. 5. erectum the angle at which the grains are placed with reference to the rachis, is much wider than in H. s. vulgare and H. s. nutans. The Svalof Station has considered the angle of the inclination of the berries as one of the more important of their notes. It is the opinion of the writer, however, that with rare exceptions it will vary directly with the density and is therefore superfluous if the latter measurement be taken. In breeding density has not been ut1lized as fully as its value seems to warrant. Voss, Koernické, and Atterber $\frac{3}{5}$, have all used it in group classification, and

1 Voss: Journal fur Landwirthschaft, 1885.

2 $\quad$ Koernicke, Friedr.: Die Arten und Varietaten des Getreldes, Berlin, 1885, p. 148

3 Atterberg, Albert: Die Varietaten und Formen der Gerste. Journal fur Landwirtschaft, 1889, 47 pp. 1-44. 

Paris, 1910.

4 and the buedero of the sralof station Atterberg and Blaringhem, have used it in studies of variation and purity, but in the opinion of the writer, 1ts possibilities in the isolation of types and in the identification of strains, hase been far from exhausted. In the years from 1909 to 2913 a close $\mathbf{s}$ tudy of density was made, both upon general farms and in experiment station nurseries. In this study 100 spikes of each variety were taken without other cholce than that they were not diseased or ciwarfed. On each of these spikes ten internodes of the rachis were measured; that is, the distance between six spikelets on one side of the rachis. From these measurements the number of internodes per decimeter was computed and this number taken as a statement of density, the Pormula was then $D=\frac{100}{L}$ where $L$ was the measurement in millimeters of ten internodes of the rachis. 
statement of density more definite, disturbs the natural

curve of the measurements to some extent. In all densities below thirty-one the tendency is to condense the groups, above that figure the opposite is true. The worst effect, that of bunching the figures when two length measurements Pall upon the same density, was avotded by the use of eractions. None of the curves have been smoothed, however, and it will be noticed that those of the greater densities especially, sre slightly rough. This roughness is more nathematical than real, but 1t seemed more desirable to present the figures as they were than to make them $\mathrm{st111}$ more artificial by sinoothing them.

In a pedigree strain the curve of density is normally sharp with a single summit. If the seeding is not pure, or if the heads from two plots become mixed, the curve is plattened and is characterized by more than one 
surmit. Although included for another reason, the normal curve of a pedigree barley is well lllustrated in Fig. 11. When this is compared with the curve of the field sample of Manchuria shown in Fig. 9, the significance of density is reedily appreciated, especially when it is remembered that the Manchurie is what is known as a variety and contains no types that merge into such other six-rowed varieties as Bey Browing or Odessa.

That density of selections is an accurate and comparable note in a nursery where the object is to secure like conditions for all selections, is shown in Pig. 10. Sandrel was incluced twice in the 1913 planting. The beds vere separated by such an interval as to represent the extremes of soll variation in the nursery. The difference in density is very slight. The summits of the curves are separated by only one unit space, but even this is seen to 
be too great when the entire curves are considered. Although the second sumit is on 27 there are 46 spikes whose density is less than that number and only trelve whose density is grester. The actual separation is nearer five-tenths of a space. The degree of separation afforded by a difference of only two internodes to the decimeter is shown 1n Pig. 12. These are two selections of Nanchurta barley taken at rancom from Table $\nabla$. By chance they are somewhat more ideal than the average strain in the same table. A difference of only two spaces in density, when taken alone, is perhaps too slight a basis upon which to separate strains, yet as is shown in the flgure, the pleld of actual merifing is very 11 ttle.

\section{The value of this character in the nursery 1s} shown in $\mathbb{7}$ ig. 12. Thase barleys are all closely related pedigree stralns of Ifanchuria. Host of then were from head selections made upon farms in south-sastern Minnesota. 
The curve represents the sumits of the curves of densities of the individual selections. The variation is considerable and is sufficient to establish some differences of 1tself. It 1s, however, only when several characters are compared that the full value of any note is apparent. For this purpose, the date of the emergence of the beard is placed in the same eigurs. As they are in no way parallel, the combination of the two curves more than doubles the value of each. It will be noticed that Nos. 3,6 , and 55 are susplciously similar, as their density and the date of emergence of the awns of each are 1dentical. The records show that the emergence was also on the same date the previous year. No. 55 is proven to be distinct by the nature of the rachilla, but the date of heading, tine of stooling, etc., are parallel in Nos. 3 and 6 and there is Iittle doubt but that they are identical. 
While not pertinent to this phase of the dis-

cussion, the curve of density and the curve of mergence

of beards is almost opposite in the Manchuria barley. In

other words, there seens to be a direct correlation between

density and earliness. In Pig. 13, which assembles o nimber

of other types of $s i x$-rowed barleys, that are for the most

part not closely related, this is not true.

The first five selections in P1G. 13 are from

e. commercial varlety known as Odesse. This so called

variety seems to be a loose assemblage of widely varying

types which are, however, ones not cormon in other six-

rowed barleys. The component strains are not nearly s.s

closely related as are those of the Hanchuria. That this

varlety itself is of hybrid origin, or that there has been

crossing between its members, is indicated in Pig. 14 . This

selection, the most dense of those made from the Odessa 
variety, proved unstable. The number of plants bearing dense heads was 71 as opposed to 16 for the looser ones. While a character need not be invariable under all conditions to be useful, a test was made to discover the affect of soil and climate. Six selections were planted at St. Paul, Minnesota; Chico, California; and at Aberdeen, Idaho. At the latter place they were grown both under 1rrigation and upon dry land. The measurements at st. Paul and Aberdeen were made by the writer, while those at Californla were made by Ur. F. I. Adams. The result is shown in Fig. 15. As a whole the variations were parallel. Nos. 6 and 35 were strikingly so. The four less dense selections showed an extreme variation of only three spaces. The two dense selections varied much more. In No. 32 this was in part due to poorly developed heads. At Irinnesota particularly, spikes were so short that it was impossible 
to flnd many in which five successive nodes bore fertile

florets. The effect of steriofty is to lengthen the internodi. All types were most dense at Chico, and least dense a. St. Paul. The effect of water, as shown at Aberdeen, Has very slight, especially when compared with the effect of the combined factors of geographical location. The character of the curves was influenced even less than their relative density. By referring to Table 5 it will be seen that some selections always present a much sharper curve than others, and thus afford opportunity for varietal distinctions in the distribution of the measurements. Avolding the extreme examples, No. 30, for instance, which has already been condensed three or four spaces by the use of the formula of density, is still less compact than No. 35, which has been made slightly less compact by the same operation. At St. Paul No. 35 has a total of $85 \%$ or 1 ts spikes in three spaces in one instance, and $91 \%$ in 
the other, while No. 30 has but $82 \%$. At Aberdeen, Idaho, under Irrigation, No. 35 has a total of $91 \%$ of its spikes in three spaces, while No. 30 has but $78 \%$. Upon the dry farm at the same place, No. 35 has a total of $81 \%$ of its spikes in three spaces, while No. 30 has but $77 \%$. At Chico No. 35 has $94 \%$ of its spikes in three spaces, while No. 30 has $91 \%$. 
PLRTILTTY.

The variation in fertility is the most evicient

and the most vital of all the modifications that occur in

barley. At each node of the rachis is produced a group of three single flowered spikelets. In the six-rowed, each of these develops a separate Brain. As the groups of spikelets are placed alternately on opposite sides of the rachis, the result is $\mathrm{s} 1 \mathrm{x}$ columns of grains from the base to the tip of the spike. In the two-rowed, only the central spikelet at each node is fertile, and therePore there are but two columns of grains. Th1s reduction does not take place by the elimination of the outer spikelets, but by their sterility. The median floret of each set of three accomplishes its normal development. On either side are the small, undeveloped, infertile, florets. However, the sexual organs have not disappeared. The 
three stanens reach an appreciable size and the ovary, though rudimentary in some ways, persists even to the plumose stigma.

There is, in one Eroup of the two-rowed barleys, a st1ll farther modification of the lateral florets. In Abysinia there is a considerable number of forms in which the side spikelets are rudimentary; that is, they no longer contain even infertile flowers, the whole spikelet being reduced to structures that are little more than hair-like. In the experience of the writer, these well known taxonomic divisions have proved entirely stable. The observations have included hundreds of varieties, and these varieties have been grown under such varying conditions as to stimulate monstrous developments in many structures, but in no case has there been indication of bridging over these separations. It is the opinion of the writer that the numerous instances recorded have been misinterpreted. 
The one cited by Koernicke was most probably a cross, as the variation of the progeny was such as is always secured by hybridization. The more common exceptions usually described are the occurrence of three and elight rowed freaks, and two-rowed barleys in which some of the lateral florets are fertile. All three are probably due to the formation of adventitious spikelets. Such spikelets are common, and if several occur along one side of the rachis of a two-rowed barley, the result is a three-rowed spike. If a duplication of the groups of spikelets at the nodes of one side of the rachis occurs in a six-rowed barley, the result is nine rows, which, if imperfect in any way, are easily mistaken for eight. It is entirely possible that florets of lateral splkelets of two-rowed varieties are sometimes fertile, but in practically all of the numerous cases that have been noted by the writer, a close inspection of such grains has shown them to be adventitious, 
and that the storile floret was also present.

$$
\text { Aslde from the observations upon established }
$$

forma, 1t has been the fortune of the investigation to 1eolate a number of which thore acems to be no publishod deacriptions. Theas all oane Sroa Abysainian barleys, and as the work is not yet aonpleted, only a general Ind1cation of the results need be given here. The group of two-rowed barleys with rudinentary fiorsta seona much larger than has beon previously thought. They vary from tho w1de seocrithon-21ke types to narroz autana-1.1ke forns, and through a series of oolors and oominstiona of colora. In barleya received from the sewe regton, there Is a group with a dur1ous 1rregular, jet heritable, habit of rloret abortion. In the ripened apike the spikelets are normal at the base and for a varying distance towards the tip. The upper postition usually reduces suddenly to a two-rowed form. In this case the side spikelets are 
not merely sterile, but are represented by only the outer Blumes and the rachilla. The floret having disappeared entirely. The splkes are found to present these modifications aven when the head Pirst emerges from the boot. The actual time of the reduction has not been determined, but it is early enough so that no sear is present, indicating that the moret never started to develop. 


$$
-50-
$$

TTE RAPTY, OR OUT'RR GLURES.

The outer Blumes present but two phases. They are usually narrowly lanceolate, but in rare forms are ovate lanceolate. In the latter case the youally long awns. A few internediates are formed by combinations in which certain ones instead of all the normal outer glumes are replaced by ovate lanceolate ones. In this investigation, while numerous ovate lanceolate selections have been made, there has been nothing added to the information already at hand. 
TILE PLOVERTNG GLUMAS.

Two of the variable peatures of the plowering

glume are treated elsewhere. The toothing of the nerves

is considered with the rest of the Svalof system under a heading of that name. The color of the glumes is taken up with color of the other plant organs in the general discussion of pigmentation. Most of the remaining variable points of structure in the flowering flume are to be found in 1ts terminal appendages, which are usually awn, but may be trifurcate hoods; the nature of 1 ts base; and Its udherence, or non-adherence, to the pericarp.

\section{Awns.}

The dimensions of the awns are naturally their most apparent varieble features. There are marked varietal differences in both length and breadth of awns, but unfortunately they are so correlated with the systematic 
groups as to make them of slight use in separating nearly related strains. All the Hanna barleys have long narrow awns, the Zeocrithon and Hexastichum forms have short, rather broad, awns; and the hull-less barleys excessively broad ones. In the Manchuria group there is some suggestive variation, but it needs the support of other variants to become convincing. There is, in addition to these rather narrow variations, a still greater difference in length of awn. In these cases an abrupt and conspicuous reduction takes place. There are botanical varieties characterized by very short awns, and others in which the glume is merely pointed. Keorniake-reoprds varieties of the latter, and Mr. H. B. Derr, of the United States Department of Agriculture, secured such a form through crossing. Such variations make a very decided separation from their long-awned relatives. 
The toothing of the awn is subject to many variations, some of which are constant. The distinctions are often merely ones of degree. There are forms, especial$1 \mathrm{y}$ in the hexastichum and zeocrithon Groups in which the toothing is very profuse and the individual teeth very large. These types are constant and are inherited with no more tendency to variation than are other vegetative characters. In the Manchuria-0derbrucker barley the teeth are numerous, but only average in size, being much smaller than the ones referred to above. The two-rowed barleys of the Hanna type have fewer teeth, and those very much smaller.

There are other barleys in which the awns are smooth. In 1910 the writer isolated, from a mixed Hanna barley, a form in which the awn was smooth except for a few small teeth at the tip. In 1911 two plants were secured from an Inglish importation, belonging to a seldom 
cultivated botanical variety, in which the awns are absolutely smooth. Hybrids of this selection upon Manchurla and Bay Brewing sorts show the toothing to be dominant over the absence of teeth. In the second generation smooth awns again appeared. Regel and others have reported Regel, Robert: - Glattgrannige Gersten.

a considerable number of such barleys. Although it seems not to have been used by systematists, the tenacity of the awn has been found to be serviceable in varietal descriptions. Most barleys thresh rather easily, but there are some which will not thresh clean, no matter how much effort be expended. This character is comnonly recognized in the California barley, but exists in Nariout, some of the selections from odessa, and numerous others as well. These varieties have been grown 
at a large number of points and show no inconstancy in

this character.

There is also a difference in the persistence

of the awns. There are a few varieties that are almost deciduous. Primus, for instance, has been observed in a great variety of locations, and it always drops a large percentage of 1 ts awns as 1 t ripens. The loss of the awn in such varieties does not come about through the breaking of that organ, but by its being loosened from the Elume. It is the tissues of the glume that give way, and is thus in reality a character of that organ.

In the hooded barleys the awn of the flowering Blume is replaced by a trifurcate appendage. This is of evident monstrous origin and is connected with the awned class by no true intermediates. The exact nature of the appendage is not clear. In structure the parts appear to be the result of vegetative stimulation and are leaf-like 
in appearance. The pact that they are three in number, and that they bear rudimentary plorets, indicates that they are a partial repetition of the spikelets of an internode, the leafy segments being the flowering glumes. The character is absolutely constant.

The Base of the Flowering alume.

The method of the attachment of the lemma, or Plowering Elume, to the rachis has been shown by Atterber $\frac{6}{B}$

Atterberg, Albert: - T1dskrift Pur Landtmand, 1838. Versuchs - Stationen, 1899 , R. 36, S 23.

to be a distinguishing mark between the erectim and nutans eroups. In the nutans group the grain is attached by a very constricted band of t1ssue which, when separated, leaves the proximal extremity smooth. The surface is oblique to the long axis of the grain and presents a small horseshoe-shaped depression just above the line of attach- 
ment. In the erectum group there is more than one var1ation of form, but all are centered around an attachment to the rachis that is much broader than in nutans and the depression is absent. When the central nerve of the dorsal Elume is not too lerge and continued too far through the base, a transverse crease is found Just above the attachment. The six-rowed barleys are separated by the same means.

The Adherence of the Flowering Glume to the Pericarp.

The normal form of barley is one in which the palea are grown fast to the pericarp. There are numerous varieties in which this union does not occur. These constltute our hull-less barleys. Both forms are absolutely stable. The character offers no opportunity for minor distinctions, unless it be in such cases as Prinsess, which the Svalof station maintains has a low bushel weight due to an abnormally loose attachment of the glumes. 
THE SVATOY CHARACTHRS.

In 1838, Neergaard, of Svalof, Sweden, announced

the inost important discovery in the classification of the lesser groups of barley that has ever been brought to the attention of the world. Not only was it of exceptional intrinsie value, but it acted as a great stimulus in the study of elementary forms, and has been the cause of much of the progress that has been made in the 1solation of biotypes.

Neergaard's work was based upon the careful study of the spike. He discovered that two previously unobserved varlants were dependable morphological distinctions. These were the nature of the covering of the basal bristle, and the toothing of the inner pair of dorsal nerves. The basal bristle, which is the continuation of the rachilla of the spikelet, is clasped within the folds of the Glumes 
and is carried with the grain when it is removed from the spike in the process of threshing. The bristle is covered in some cases with long stiff hairs; in others, with short curly ones. The inner pafr of nerves upon the dorsal surface of the grain are in some cases provided with numerous small translucent teeth, in others they are smooth.

\section{The use of these two new characters gave four} separations in any group; 1. e., long haired bristle, nerves without teeth; long haired bristle, nerves with teeth; short haired bristle, nerves without teeth; and short halred bristle, nerves with teeth. When these separations were applied to the larger groups, 프. 프 erectum, ㅍ. ‥ nutans and 프. ‥ vulgare (tetrast1chum), twelve smaller groups resulted.

$$
\text { Although this new grouping was only a small }
$$

part of the Svalof observations on barley, it soon became 
known as the Svalof system, due no doubt to its novelty.

As a new departure, it has been subject to much more controversy than have most of the older and universally accepted taxonomic features.

Several breeders, among whom Broll $\frac{7}{1}$ is the most notable, have attacked the system, and declared that the characters might be trustworthy on the svalof station,

7 Broil1, Jozef: - Das Gerstenicorn im Bilde. Stuttgart, 1903

$\underline{8}$ v. Tschermak, Eric: - Die Zllchtung der Landw1rtschartlichen Kulturpelazen, Berlin, 1910, Vol.TV, p. 286.

9 Blaringhem, M. L.: - La Variation des formes Vegetales, Revue Generale de Botanique, 49-6̂6.

but when the plants were Erown under other conditdons they

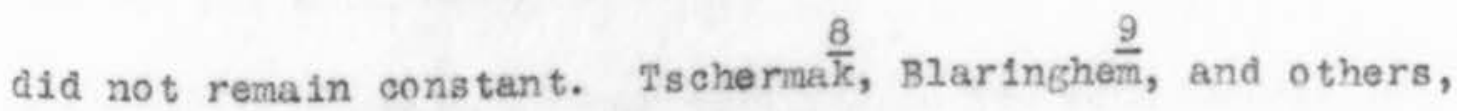
have supported the Svalor station in the matter of the basal bristle, but have not committed themselves so completely 
with reference to the toothing of the nerves.

Since the point of contention is the effect of soil and climate, observations in this country are of many times the natural value of those in Burope. The variation between California and Minnesota, or Idaho and Virginia, ropresents a range that is Impossible to a European breeder. Observations have been made upon some hundreds of selections representing all botanieal groups. Very little variation was found in the nature of the rachilla. All observations tend to credit this character with as much stability as is usually found in taxonomic work. As would naturally be expected, the toothing of the dorsal nerves has been found to be more variable and more inPluenced by elirate. The rachilla is the axis of the spikelet, a definite and vital portion of the fruiting body. The teeth on the dorsal nerves are of no vital significance, 
being mere manifestations of the epidermis. The vriter Peels that the Svalof position has here been injured by too enthusiastic defense. The fact that varlations may, or mats not, occur in a strain is of little importance-1f the linits are definable. No doubt there is variation and it is especially noticeable in the sparsely toothed varieties. A cactus under proper conditions will display leaves, yet no one w11l question the propriety of describIng the cact as leafless plants. They never become foliage plants, and no more do we expect a smooth nerved Hanna selection to show the strong toothing of the Manchurla. It mey at times present a few scattering teeth, but it would never become even moderately strongly toothed, and certainly there are strongly toothed sorts that are never anything else. 
VARTATTONS IN THE GRATN.

The grain itself varies in many ways. The

more definite variations not treated elsewhere are shape, dimensions, weight, and composition.

$$
\text { Shape of Grain. }
$$

The shape of the grain is well established as

a group distinction and is often a varietal characteristic. The six-rowed varieties are sharply set off from the tworowed by the twisting of the lateral berries. Iven the central grain of the six-rowed varieties, although it is not twisted as are the side ones, is still of a different $\mathbf{s h a p e}$ than the two-rowed. In the $s i x$-rowed the greatest diameter is nearer the distal end of the grain, while in the two-rowed it is nearer the proximal end. Within the groups the separations are, of course, less marked. Certain Finnish and Russian barleys may readily 
be distinguished from the Manchuria because of their less oval shape. The extrenities of the grain are more pointed, Giving a fusiform, or 3pindle-shaped, seed. The Goldthorpe barleys, especlally such extreme types as Standwell, are readily soparated from the other two-rowed forms. The Svalof Station reports that Mannchen and Prinsess can be readily distinguished in bulk samples by the shape of the Grain. Most of the distinctions, however, are so dependent upon the relative proportions of the grain that it is Impossible to consider shape independent of dimensions.

\section{The Dimensions of the Grain.}

The barley grain varies in length, width, and thickness. At times one, or all, of these may constitute a varietal character. No other barley could be confused with the Smyrna. Its long grain is unique. It is also very doubtful if a second strain could be found that posses- 
ses the unusual breadth of the standwell. In all but

these very extreme types, the ase of these vartants must rest upon statistical methods.

At any place the product of a variety in the same season is sufficiently uniform to give a decided indication of the average size of the grain with one hundred measurements. The size of the grain is, however, but partially dependent on variety. In Table VI is given a sumary of measurements nade upon samples of three varieties grown at various points in the United States. The collams marked "highest" and "lowest" have very little significance, but the averages are quite instructive. The variation is strangely unfform. The length; the lateral, and the dorsoventraz, diameters; of Prinsess differ each Pive-tenths of one millimeter in the averages. The dimensions of Primus vary each four-tenths, and of Chevalier IT two-tenths. It does not necessarily follow that Prinsess is the most 
variable of the three. This variety was subjected to more extreme conditions than the other two, and in two 10cations the development was hardly normal. of the threo measurements, that of length is obviously the most dopendable. The actual verietion is no greater and since it is based upon a much larger ifgure it is relatively less. Also the two diameters are more afPected by ripening conditions and therefore less serviceable for local distinetions. The length seems to be determined by varietal and climatic influances early in the life of the plant, while the diameters are dependent upon the amount of starch ineiltration at ripening time. This is well 11lustrated in the two sanples of Prinsess from Huntley, Kontana. The first was irrigated, the second was not. The length of the graing in the two were practically ident1cal, while the diameters evideneed the Brestest variation found within a variety. 
The weakness of all grain measurements is not in the variation, but in the fact that the interval between varieties is not great. The total range of averages is not large and while many selections may be told apart, a Great many more must remain inseparable because of identical, or nearly identical dimensions.

$$
\text { weight of Grain. }
$$

The thousand-berry-weight is a determination

that has been considered indispensable in the appraisement of exhibition samples, and it is also a very useful record in plant breeding. From the nature of this factor, it is to be expected that it will vary with conditions and culture, but usually the variations are more or less parallel. In this investigation certain varieties have always been found relatively high, and others relatively low, in berry weight, regardless of location or season. The character is, how- 
ever, a varietal character, and not often useful in separating related strains.

\section{Composition.}

The varietal character of any barley, as far

as composition is concerned, is subservient to climatic conditions. If it is grown in California it will be much lower in nltrogen than if it be grown in Minnesota. The average difference of ail varieties is oftenegreater than that between the two most extreme at either point. Despite this fact, there is an actual varietal tendency. Svanhals is reported in Sweden to be relatively high in nitrogen for a two-rowed barley. It is also high in this country. Samples of California Peed from many states in the west and in the plains region were analyzed. This variety was always lower in nitrogen than were other 8 ix-rowed forms. Leclerc and wahl found that the average 
10 Le Clerc, J. A., and Wahl, Robert. Chemical studies of American Barleys and Malts. United States Department of Agriculture, Bureau of Chem1stry, Bulletin 124.

protein content for Bay Brewing from all points was 10.73 per cent, while for the ordinary six-row 1 t was 11.36 per cent.

It is doubtful if a factor with such wide and easily influenced limits can be made to be of assistance in the separation of strains, save in exceptional cases. It can, however, be used in the description of varieties and may be of much iraportance in the selection of sorts adapted to satisfactory market demands. 
PIGIENTITAT ION.

Color is one of the most easily determined

characters of barley. Unfortunately it is also one of the most treacherous distinctions. The occurrence of pigments in certain cases, and in certain tissues, is undoubtedly hereditary and is transmitted unfailingly from generation to generation. In other cases the color appears intermittently, and in still others sporadically occurring in strains and tissues ordinarily free from pigments. This erratic behavior, coupled with the fact that white, brown, black, violet, purple, amber, and blue-gray have been used in various classifications, led the writer to make a study of the pigmentation of barley. Since the colors in the seed seemed to be more numerous and less variable than in the other parts of the plant, the grain was used as the basis for the investigation. 
The technique was adapted from that used by Mann in his identification and location of the pigments in

11 Mann, Albert: - Coloration of the Seedenat of Cowpeas, Journal of Research, United States Department of Agricul ture.

the cowpea. The grains were first examined by sectioning them dry. This avoided any modification such as might easily come from the action of solvents in an embedding process, or even from water if a freezing method were used. The hand sections were equally as satisfactory as those made with a microtome, as the areas in question were readily defined and the colors more easily seen in moderately thick sections than in very thin ones. The reagents most extensively employed were caustic potash, hydrochloric acid and chloral hydrate. The sections were placed dry upon a microscope slide underneath a seven-elghts inch cover glass 
held in place by a drop of paraffine on either side. The reagents were drawn beneath the cover glass by means of blotting paper and their action watched through the microscope. Two per cent solutions of the acid and the alkali, and a saturate aqueous solution of chloral hydrate, were used in these tests. If the pigment showed no change within a few minutes, the reagents were allowed to remain upon the section for some hours. In such cases larger pieces were also placed in small vials containing fifteen per cent solutions and examined at the end of twenty-four hours. It soon becarne apparent that there were two plements in barley. One was readily affected by the weak solutions, and from the naturo of its reaction was undoubtedIy anthocyanin, which occurs widely in the plant kingdom In both its red, or acld, and its blue, or alkaline, form. The other resisted even prolonged soaking in the more concentrated solutions and was probably a melanin-like substance. 
The first varieties studied were ones in which

the adhering glumes were black. To change was effected by

either the weak reagents, or the prolonged soaking in concentrated solutions. The black ald indeod become a brown, but this was most probably due to the distention of the pigment containing tissues, attendant upon the absorbtion of water. As a considerable number of varieties with black glumes were tested, and as the results were uniformly the same, it would seern that a black or brown pigment in the elumes may be attributed to a melanin-like compound.

$$
\text { A number of Abysinian varieties with purple }
$$

glumes were sectioned and treated with the reagents. The purple color responded at once to weak solutions. It immediately became blue when treated with the alkal1, and became red again when the acld was applied. The chloral hydrate test here, and in all other instances, was less 
definite than is the case with most anthocyanin deposits. Upon its application the red color faded very slowly until the natural yellow of the glumes became apparent. The red Immediately returned when acid was added. There is no reasonable doubt but that the color in these barleys is due to anthocyanin.

\section{A hull-less barley with a violet or purple}

pericarp was exanined. The color was also readily demonstrated to be anthocyanin. In this instance, as in some others, the pignent was found both in the pericarp and in the aleuron layer. In the former tissue 1 was red, and in the latter blue. When treated with acid the red of course was unchanged, while the blue also becane red, intens1fying the effect very much.

In all barleys studied, the anthosyanin was always red in the pericarp and Elumes, and always blue in the aleuron layer. In other words, the resting condition 
of the protoplasm was alkaline, while the inert tissue seemed to be in an acid condition.

A new form of hull-less barley lsolated from an Abysinian importation gave striking testimony of the systematic value of the distinction between the two pignents. Th1s selection has a dense black periearp. It was absoIutely resistent to all concentrations of reagents, showing the p1ement to be melanin-11ke. As far as the writer can learn, there is no other naked barley of the nutans group In which this piement occurs, and this botanical form has no published description.

The last variety studied was 프. ㅁ. pall1dum goerulescens. This variety has the peculiar blue color well known upon the market in Cal1fornian, Ch1lian, and 11ke barleys. The oolor has been held to be variable by both grain dealers and soientists. Regel explains 1 ts lack of stability by calling it a hybrid form. Examination 
showed the color to be due to a deposit of anthocyanin in the aleuron layer. This layer was readily changed to red by the application of acid, and as readily made blue again by the use of alkald.

The stabllity of this and other forms was studied in the pields. Anthocyonin seems likely to be found in any plant and in any part of the plant. It seems to appear abnormally in cases of malnutrition, and is very likely to occur in conductive tissues that are ceasing to be functional. It has, however, a normal phase in the grain. In certain hull-less forms 1 ts stability is unquestioned and, to the writer's mind, its variability in coerulencens has been over estimated. The hybrid theory of Regel in coerulescens becomes untenable when two piements are admitted. If an internediate, it could be so only between a white variety and a black one. This is evidently impossible because a cross batween a form w1th a melanin-like 
pliznent and one with no plement could not result in one characterized by the production of anthocyanin. The wide spread opinion of variability is possibly due to fauly observation. The deposit is in the aleuron layer and the color is sometimes obscured by the glume. The weathering of this organ, especially in humid areas, greatly lessens its transparency. The aleuron layer is covered by both pericarp and hulls. The color must not only be a pronounced one to enable one to detect it from without, but the coverings must also be passibly transparent. When ripening occurs In rainy weather, this is not the case, and the hulls must be removed in order to make a trustworthy detemination. Malstars often speak of the blue grains that appear after steeping; that 1s, when the coverings have become transparent. There is undoubtedly a diffarence in the amount of the pigment deposited from year to year. Part of this may be due to the conditions of growth, and part to the 
conditions of ripening. This pigment, like melanin, is

formed during the later stages of growth. It may be that

an abbreviation of the ripening period, due to heat or

drought, would result in a reduction of pigment.

The inheritance of the character has been tested

by observations upon several strains 1solated from various

barleys. These have been grown for several years and at

a number of places, and in every instance the aleuron layer

has retalned a decided amount of blue color.

The black colors have become more nearly brown

in some places, but have never disappeared. Blue-gray and violet-purple colors in hull-less barleys are due to blue anthocyanin in the aleuron layer, combined with a pigment Pree pericarp in the blue-gray and with a red anthocyanin deposit in the violet. Both are unquestionably inherited. Minor phases of anthocyanin formation are found in the follage of the plant, the nerves of the grain, and 
in the awn. A red foliage, although found more commonly in some forms than others, may ordinarily be disregarded. In most cases it indiates a malnutrition of some sort of other. In the nerves of the dorsal flowering glume it may be more valuable as a distinction. A Ereat many barleys show this character to some extent. IJven the Hanna races possess violet or purple nerves just before ripening. None, however, develop the color to the degree that is attained by some of the Russian and Asiatic forms. In the barley nursery are several Russian selections in which the stripes along the nerves are so broad that the grains are almost red. The same is true of the strain known as Kashgar, which was imported from the region of that name in India. In the awn an apparent anomaly was noted in 2911. In the same selection some spikes were observed in which each awn was marked with two parallel stripes of red extending from its base to 1 ts tip, and other spikes in which the 
same bars were deep purple. When examined in the laboratory, the color proved to be two bright red stripes in the ep1demis, below which were two chlorophyli-bearing parenchym areas running the full length of the awn. As long as the chlorophyli was present the color effect was deep purple, as soon as this disappeared it was 11 ght red. 
SUMTARY.

While all lesser distinetions must be based upon the broader groups, and no study of a cereal couzd oinit 1ts classification; the plant cheracters useful in taxonomic work, and the ones most useful in plant breoding, are far from being the sane. Plant broeding is concerned with minute differences. The broed systematic divisions are serviceable only as groups. The problem of the nursery is not to separate a six-rowed Manchuria from a two-rowed Heme barley, but to detect a variant in a plot of Manchuria. Strains are often shown to be distinct in early Growth by their rate of development. All barleys rush through the early stages very rapidzy and a selection that is one or two days earlier thas a seond is very dissimilar in appearance.

Leal production 1s, in some ways, a var1etal character. In some varieties the third leaf appears in 
three days after the second, in others it occurs six days later. In the fourth leaf even a greater range exists. In some strains the first tiller occurs decidedly later than the fourth leaf. In others it appears earlier. In some the tillers are all produced within a short time; in others the process is extended over several days. The emergence of the awn is an extremely importany note, as it occurs at a time in the life of the plant when such an observation is of great value. The development is usually normal at this time, as hot weather and drought have ordinarily not yet had any effect. The emerEence of the awn has been found to be far more accurate and more easily obtained than the date of heading.

The precocity of strain at the time of the emergence of the awn is a heritable character.

The date of ripening is, unfortunately, often influenced by season, and while a valuable character, is 
less dependable than the emergence of the awns.

A comparison of the development during all stages serves to reveal many differences not apparent when taken separately.

The length of culm is of use as a local breeding note, but the variations are not parallel when strains are planted in totally different areas.

The diameter of the culm is not serviceable because nearly related barleys have culms of approximately the same size.

The thickness of the walls of the culm is a note with a large experimental error, and therefore of questionable utility.

The degree of exsertion of the splike is sometimes a varietal character, but is not often useful. The number of culms per plant is to some extent a varietal character, but selections are so affected by 
season and location that it is very difficult to use.

The widh of leaves is useful in group distinctions, and sometimes in varietal separations.

The length is much less dependable and is serviceable only in rather extreme types.

The number of leaves varies with the groups, but usually closely related strains possess approximately the same number of leaves. The density of the spike may easily be made the basis of many separations. Often varieties that show no other differences are widely dissimilar in density. The density of a selection varies somewhat with season and location, but the mean is always sharply defined, and the Pluctuations more or less parallel.

In some strains all spikes conform closely to the mean. In others the range is greater. This seems to be a varietal character and is true whether the plantings 


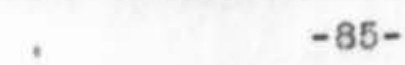

are made in California or Minnesota.

The established systematic groups based upon the relative fertility were found to be invariable under

all extremes of American climate.

The natural varleties in the deflciens group of Abysinian barleys seem more extensive than most classirications have indicated.

From barleys of this same region a group with

a peculiar habit of floret abortion has been isolated.

The length and width of awns vary, but are so

correlated with other systematic characters that they are seldom useful in close separations.

The tenacity of the awn 1 s frequently a varietal character unaffected by location or season.

The character of the basal bristle has been

found to be stable under American conditions. The toothing of the inner peir of dorsal nerves 
is much more variable, but the variation is usually within definable limtts.

The length of the grain, while influenced by climate, is a varietal character.

The lateral and dorso-ventral diameters are so to some degree, but are so influenced by conditions of growth as to become confusing in most instances. The composition of the grain is a varietal character, but one dominated by climate. There are two coloring materials in barley: one, anthocyanin, is red in 1ts acid, and blue in its alkaIine, condition. The other, a melanin-like compound, is black. The pigments may occur in the hulls, the perioarp, the aleuron layer, and occaslonally in the starch endosperm. The resulting colors of the grain are quits complicated. The absence of all pigment is white. A heavy deposit of the melanin-like compound in the hulls is black; a $11 \mathrm{ght}$ 
deposit, brown. Anthocyanin in the hulls is a light violetred. In hull-less forms the melanin-like compound in the pericarp results in a bleck grain. Anthooyanin produces a violet one. The acid condition of anthocyanin in the pericarp superimposed upon the sukaline condition in the aleuron layer gives the effect of a purple color, while a blue aleuron beneath a colorless pericarp is blue-gray. White hulls over a blue aleuron causes the grain to appear bluish, or bluish-gray. Black hulls over a blue aleuron give, of course, a black appearance. The anthocyanin is always violet in the hulls and pericarp and always blue in the aleuron layer, showing the former tissues to be in an acid, and the latter in an alkaline, condition. The occurrence of anthocyanin in the pericarp of hull-less barleys is more significant than 1 ts production in the aleuron layer. 
TABIE I. - The relation of geographical location to length of culm in thirteen representative selections. The selections are arranged in order of their height at each point.

St. Paul, Minn. Williston, N. D. Moceasin, Mont. Chico, Calle.

\begin{tabular}{llll} 
Hordeum vulgare & Servian & Odessa & S.P.T.No.20375 \\
Oderbrucker & Odessa & H. vulgare & Oderbrucker \\
Ianchuria & H. vulgare & Surprise & Abyssinian \\
Sumit & Smyrna & Sumit & Servian \\
Prinsess & Oderbrucker & Servian & Smyrna \\
Surprise & Manchuria & S.P.I.No.20375 & Manchuria \\
Servian & Sumit & Kitzing six-row & Summit \\
S.P.I.No.20375 & Surprise & Manchuria & Odessa \\
Ritzing two-row Kitzing six-row & Oderbrucker & Kitzing six-row \\
Ritzing six-row & S.P.T.No.20375 & Smyrna & Prinsess \\
Abysinian & Prinsess & Abyssinian & Kitzing two-row \\
Smyrna & Abysinian & Kitzing two-row & Surprise \\
Odessa & Kitzing two-row & Prinsess & H. vulgare \\
\hline
\end{tabular}


Table IT. - The effect of interval on the production of culms in selections of smyrna and Manchuria barley.

4 in. by 8 in. 4 in. by 4 in. 4 in. by 2 in. Man- Yan- Manchuria Smyrna churia Smyrna churia Sinyrna

\begin{tabular}{lrrrrrr} 
Total plants & 42 & 46 & 87 & 80 & 179 & \multicolumn{1}{c}{190} \\
Total culms & 122 & 282 & 234 & 361 & 236 & 446 \\
Culms per plant & 2.9 & 6.1 & 2.7 & 4.5 & 1.3 & 2.3
\end{tabular}

The selection of Manchuria was chosen for 1ts low tillering habit, and is not typical of the Nanchuria varlety of commerce. 
TABLI III. - Average measurements of twenty-five leaves in selections from prominent types of barley grown at $\mathrm{st}$. Paul, Minnesota, in 1911. The width is Given in millimeters and the length in centimeters.

Pedigreed selection

Prinsess

K1taing two-rowi5.5 H. s. deficiens Oderbruoker Hanchuria oderbrucker Summ1t K1tzing six-row20.0 Surprise Servian Odessa Abysinian Proskowe tz

16.0

17.5 20.0 22.0 15.5 20.0 20.0 15.0 22.0 16.0 w1dth Highest Lowest Average
12.5 27. 0 12.5 14.0 14.0 15.0 12.5 16.5 16.5 15.5 21.0 17.0 11. 0
13.2 1.2. 7

13.7

15.5

16.7

13.7

14.3

18.5

28.3

17.8

13. 7

18. 7

13.0
Length

H1ghest Jowest Average

28

28

32

23

27

28

26

26

26

25

22

25

28
$20 \quad 23.5$

$20 \quad 23.7$

$26 \quad 28.7$

$17 \quad 19.2$

$18 \quad 22.8$

$20 \quad 24.3$

$18 \quad 22.5$

$18 \quad 22.6$

19.522 .9 $20 \quad 22.8$

$14 \quad 27.9$

$20 \quad 22.0$

$23 \quad 25.5$ 
TABTis IV. - The width and length of leaves in the common groups of barley grown at St. Paul, Minnesota, 1911.

Group.

H. s. erectum

$\frac{\text { H. s. nutans }}{\text { Iong haired }}$

short halred

H. s. vulgare

Manchuria types long halred short haired, wh1 te

blue aleuron

Russian types

H. 8. hexast1chum

\begin{tabular}{crrrrrr} 
No. & \multicolumn{3}{c}{$\begin{array}{c}\text { W1dth } \\
\text { H1gh- Low- Avg. High- Low- } \\
\text { est } \\
\text { est }\end{array}$} & $\begin{array}{c}\text { Length } \\
\text { est }\end{array}$ & Avg. \\
11 & 17 & 13 & 14.0 & 26 & 22 & 23.9 \\
67 & 14 & 9 & 11.4 & 27 & 20 & 23.0 \\
18 & 18 & 10 & 13.628 & 20 & 24.2 \\
49 & 18 & 13 & 16.125 & 20 & 22.6 \\
85 & 20 & 15 & 17.7 & 26 & 22 & 23.7 \\
34 & 19 & 14 & 16.825 & 21 & 23.3 \\
23 & 19 & 13 & 17.027 & 22 & 23.7 \\
29 & 19 & 10 & 15.426 & 19 & 22.2
\end{tabular}


TABIS
Name

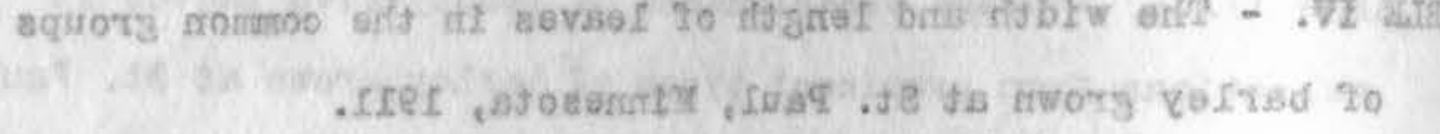

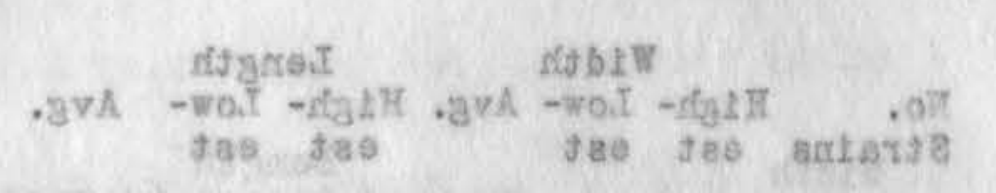

6.85 as as 0.25 at if as

0, es os is t.f. e di pa

s.se os ss o.es of af af

o.se os as f.or if ar ga

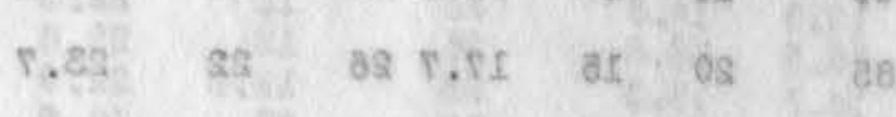

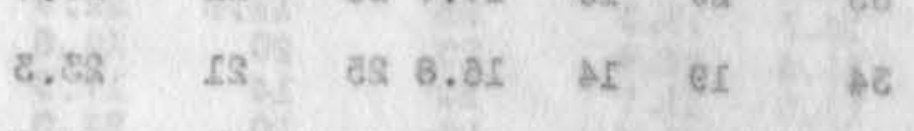

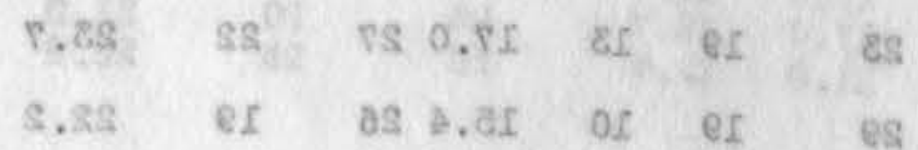

Uanchuria
Servian

ขพองก

Meyer
Lake City
Triangular

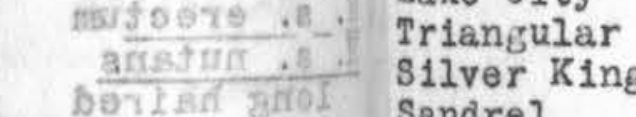

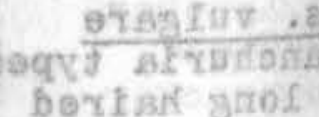

os

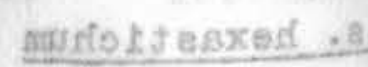

Place

st.

St. Paun, Minn.

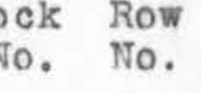

" "

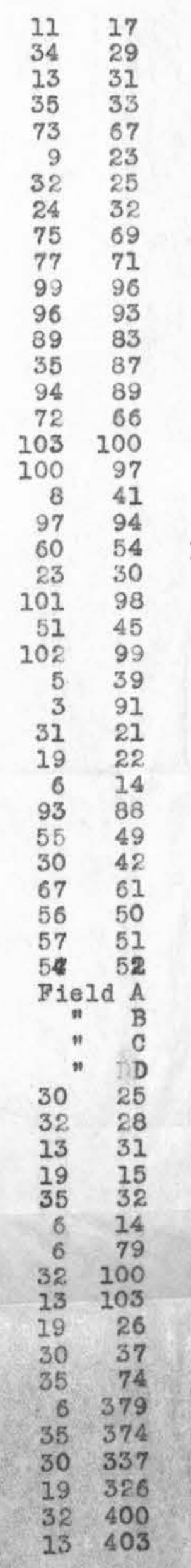

$\begin{array}{llllllll}25 & 26 & 27 & 28 & 29 & \text { Number of internodes } & \text { in } \\ 30 & 32 & 33 & 34\end{array}$

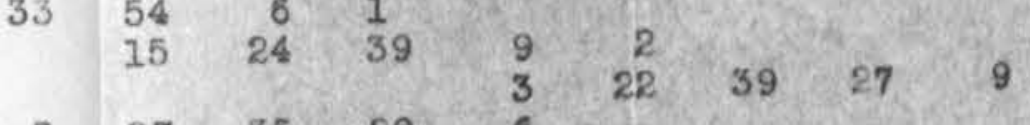

$\begin{array}{rrrrrrrrrrr}27 & 35 & 29 & 6 & 6 & 20 & 9 & 3 & & & \\ 1 & 4 & 30 & 33 & 20 & 9 & 7 & 21 \\ 6 & 10 & 15 & 1 & \frac{1}{7} & 16 & 31 & 24 & 11 & 5 & 1\end{array}$

$\begin{array}{llllllllll}3 & 15 & 23 & 39 & 8 & 2 & 2 & & & \\ & 4 & 19 & 32 & 33 & 10 & 2 & \\ & 4 & 3 & 14 & 36 & 32 & 13 & 2\end{array}$

$\begin{array}{rrrrrrrrrr}10 & 35 & 34 & 19 & 1 & 1 & 47 & 26 & 5 & 3 \\ & & 1 & 18 & 40 & 41 & 26 & 9\end{array}$

\begin{tabular}{cccc} 
& 12 & 34 & 42 \\
2 & 8 & 28 & 49 \\
2 & 12 & 34 & 32 \\
1 & 13 & 32 & 47 \\
11 & 35 & 36 & 15 \\
\hline & 3 & &
\end{tabular}

$\begin{array}{ll}1 & 10 \\ 16 & 35\end{array}$

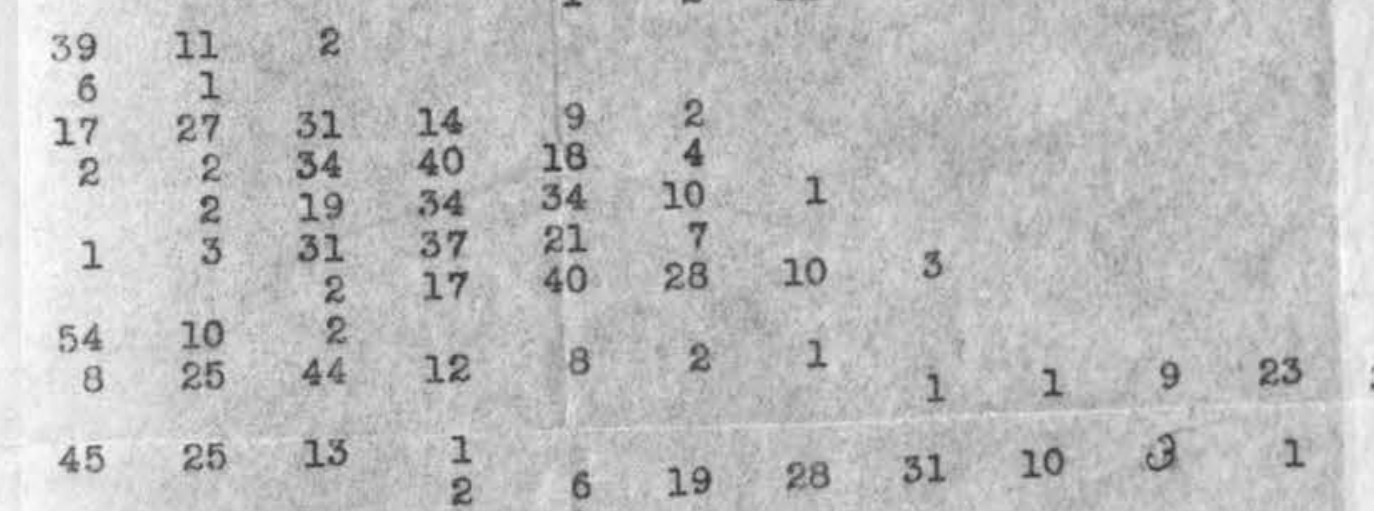

\begin{tabular}{rrrrrr}
2 & 5 & 16 & 37 & 24 & 13 \\
6 & 15 & 26 & 41 & 10 & 1 \\
\hline
\end{tabular}

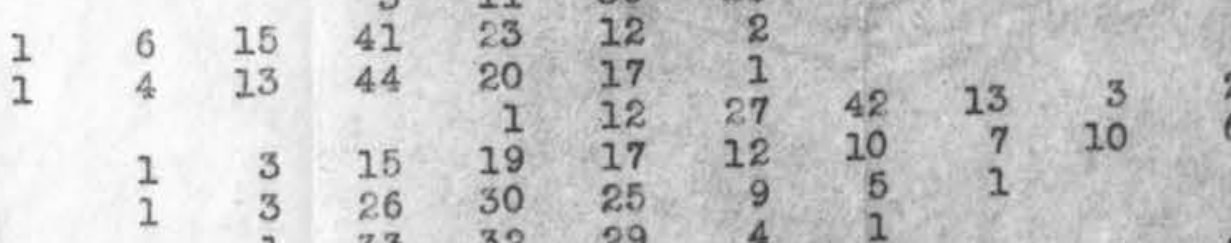

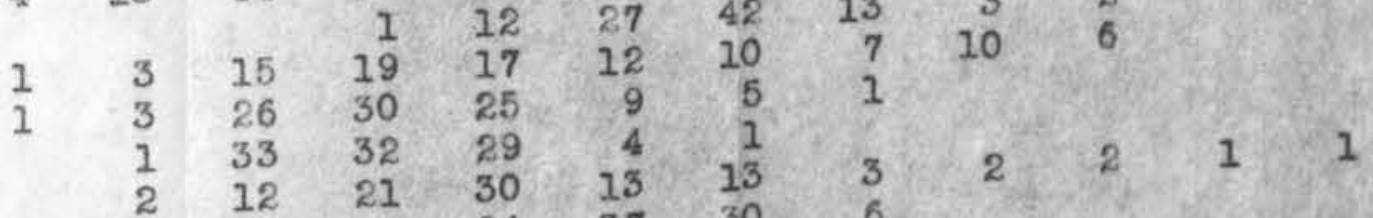

$\begin{array}{llllllllllll}1 & 33 & 32 & 29 & 4 & 13 & 3 & 2 & 2 & 1 & 1 & 1\end{array}$

Itainan
Mariout

Sagle
Sanhals
Sandrel

Peatherston
Peatherston
Yariout

$\ln (t)$
tandian

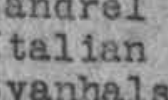

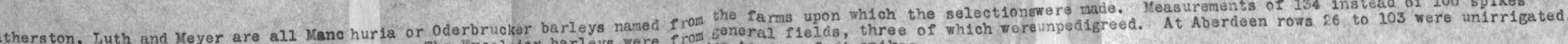

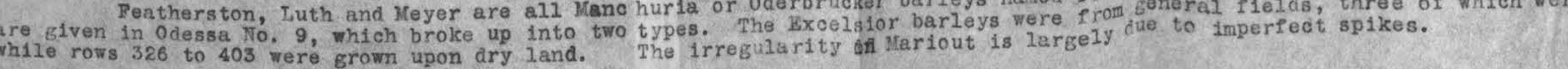




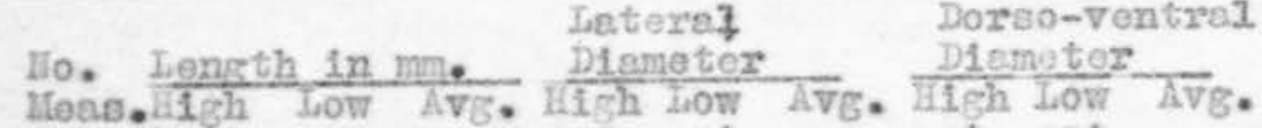

Prinsess

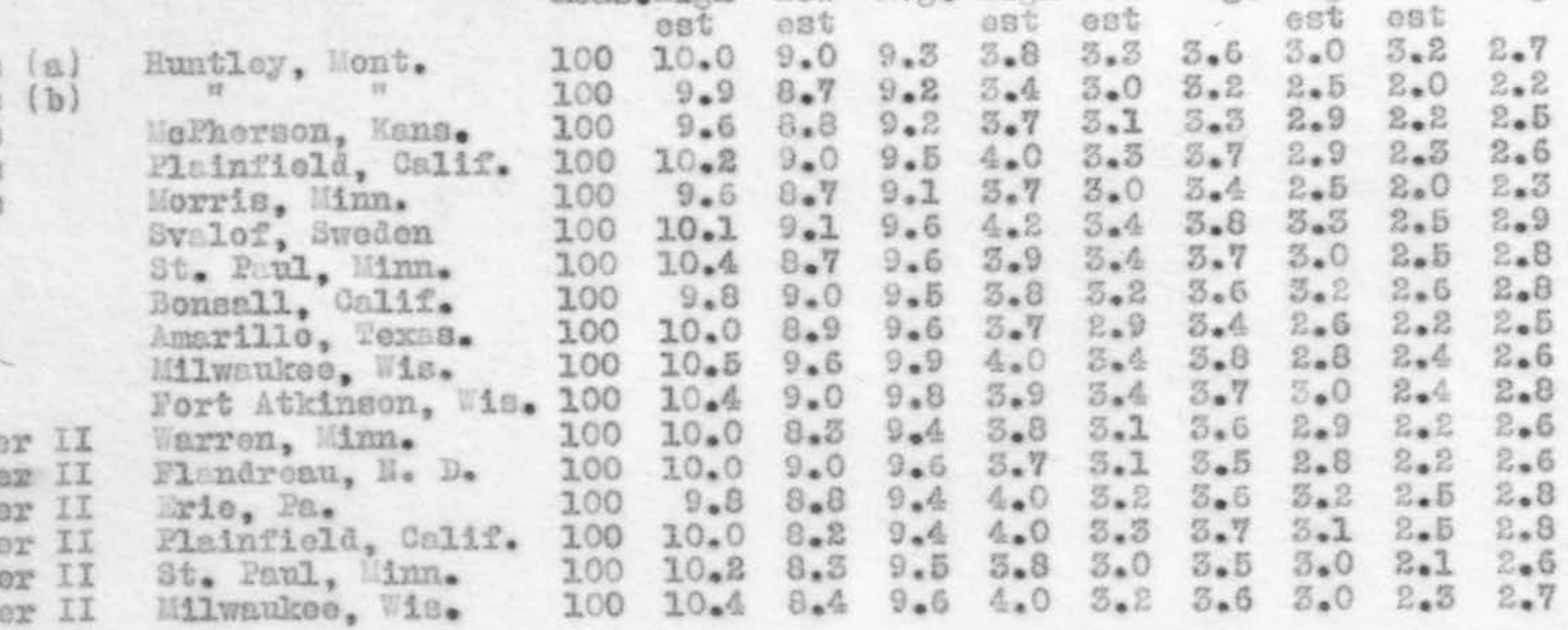

Prinsese

Prinseas

Prinees8

Primus

Primua

Primus

Primus

Primus

Primus

Chovelier II

Ghoraltor II

Chevelior II

Chevelior If

Chevelior II

Choveliex II

Lilvanices, W18. 100

10.4

Barmie (a) of tho Irinsess barley from Iuntiey Hont., wae grom upon ixrigeted. Ind, while somple (b) was grown upon tho dry Pszi: 
Fig. 1. - The Occurrence of the Second, Third and Fourtl Leaves, and of the First Tiller in Ninety-six Plantal of Oderbrucker, Selection Number 50. The houjulan,

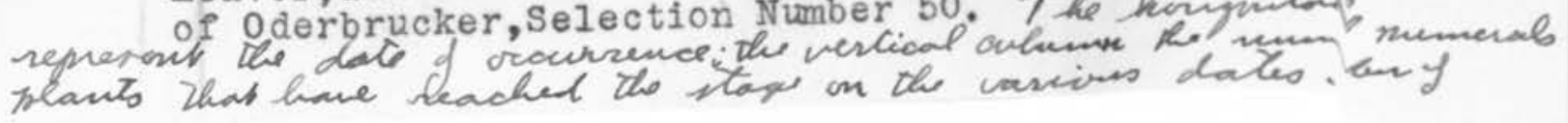





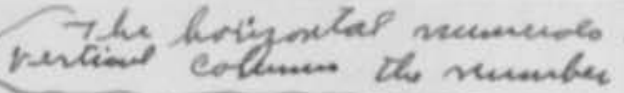

P1g. 2. - Varietal Differences in the Rapidity of T1llering. In Eagle, No. 13, All Plants Produce T1llers Almost Simultaneously, While in Russian, No. 21, the Process Is Bxtended Over Many Days. 


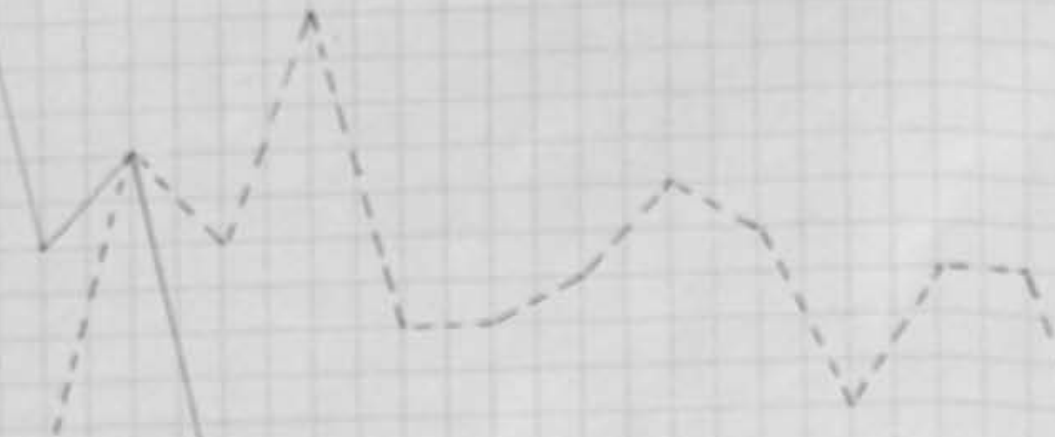

$26 \quad 27$ is 47 26.21 
Fig. 3. - The Average Date of the Production of the Second and Third Leaves, and the First Tiller in One Hundred Plants of Each of Seventeen Selections Grown

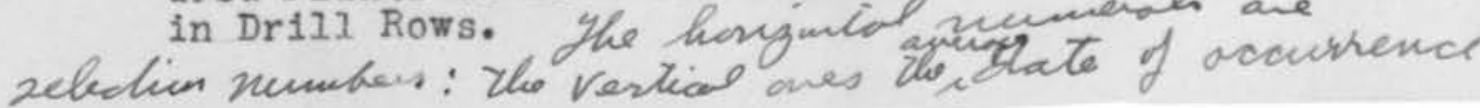


7

6

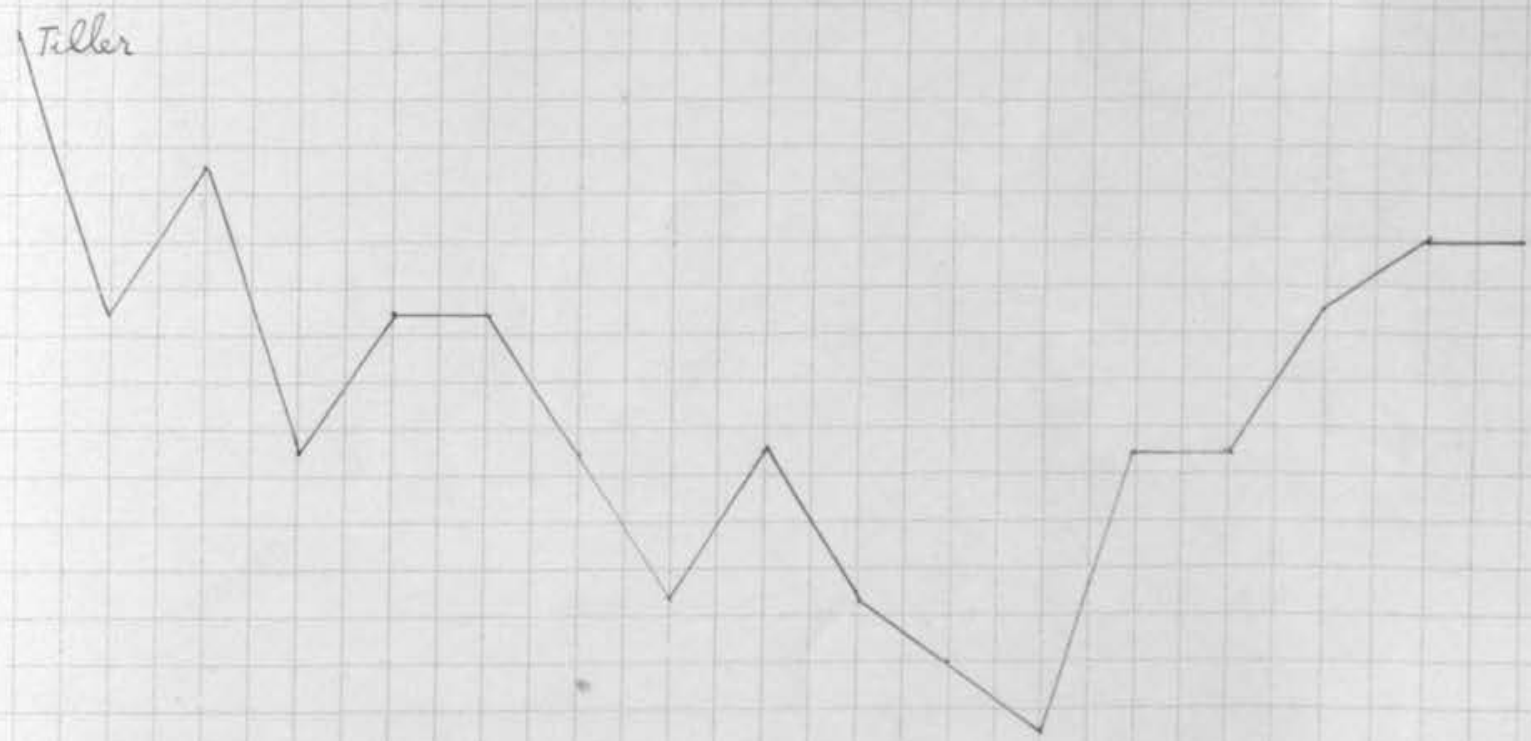

Third teof

3

2

3

4

5

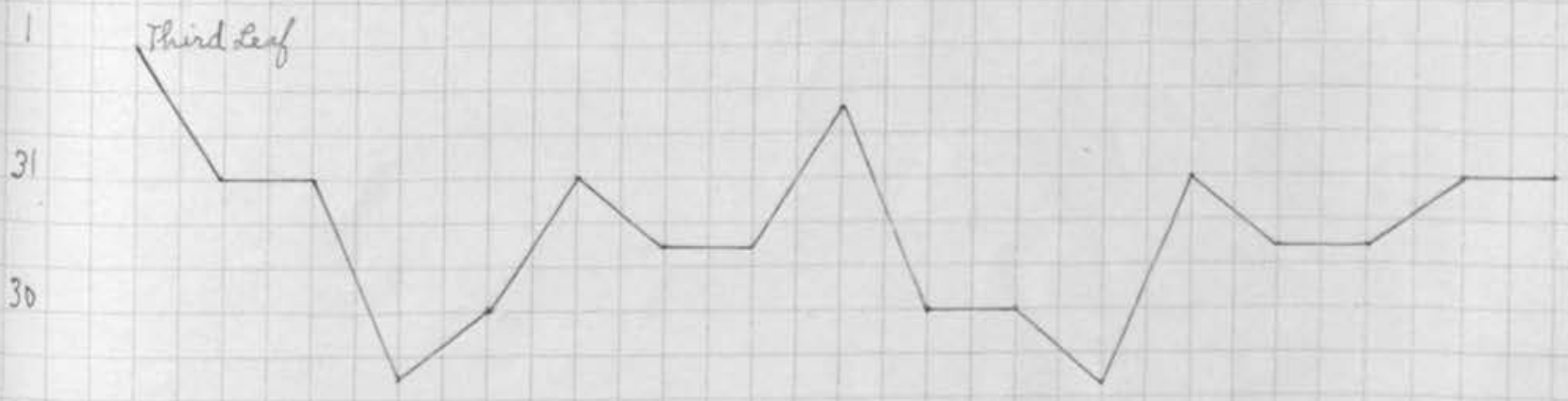

29

28

27

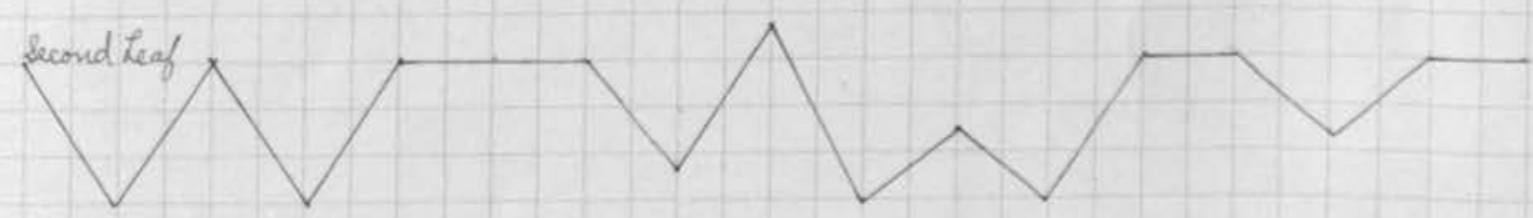

26

25

$\begin{array}{lllllllllllllllll}21 & 23 & 9 & 24 & 5 & 17 & 2 & 28 & 36 & 29 & 13 & 90 & 34 & 31 & 9 & 32 & 93\end{array}$ 
P1g. 4. - Summary of the Rmergence of the Awns in 13,108

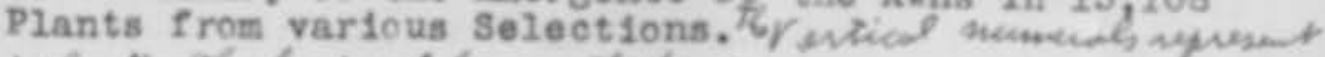

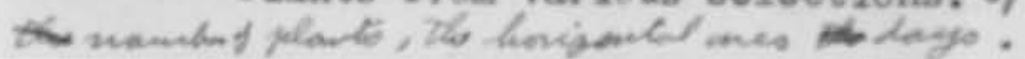




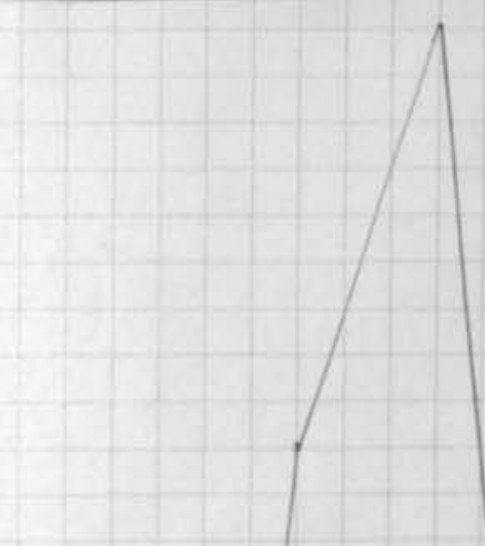


Fig. 5. - The Bffect of Season upon the Relative Date of the Imergence of the Awns in Thirty-seven Selections of S1x-rowed Barley Grown at St. Paul, Kinn., in 1911,1912 and 1913. represant the dates, che aledin numbers. 


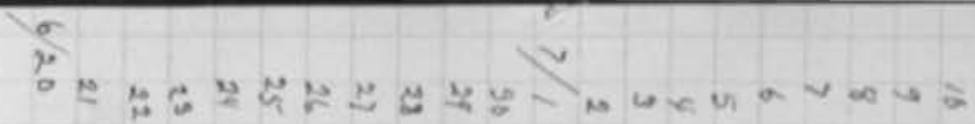

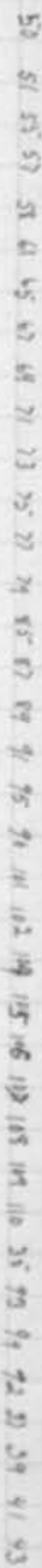

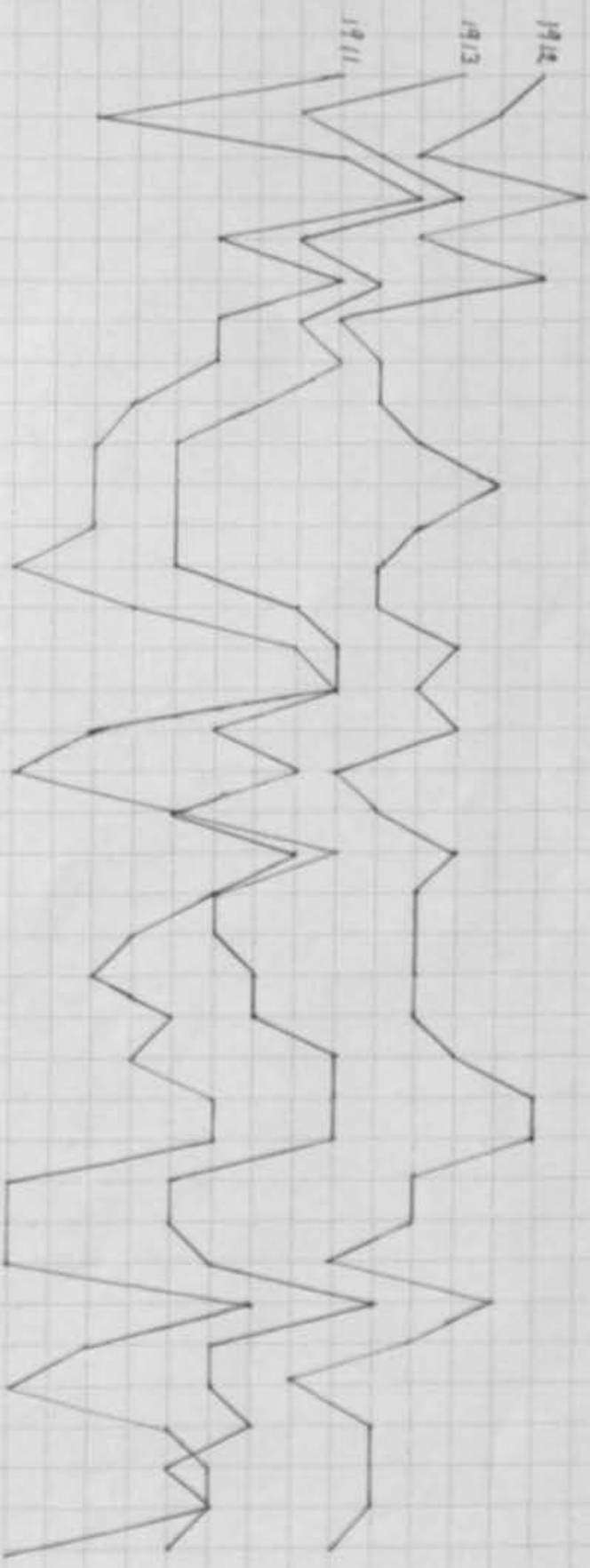


F1g. 6. - The Ripening of Bach of 1541 Spikes on a Plot of Manchuria Barley, Stated in Days From Date of Planting. Vhe wertidal numerals are number of ofessich

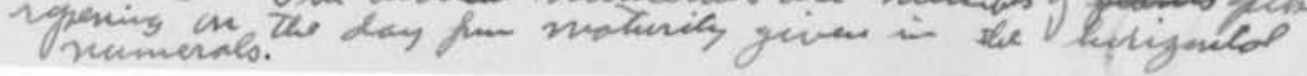




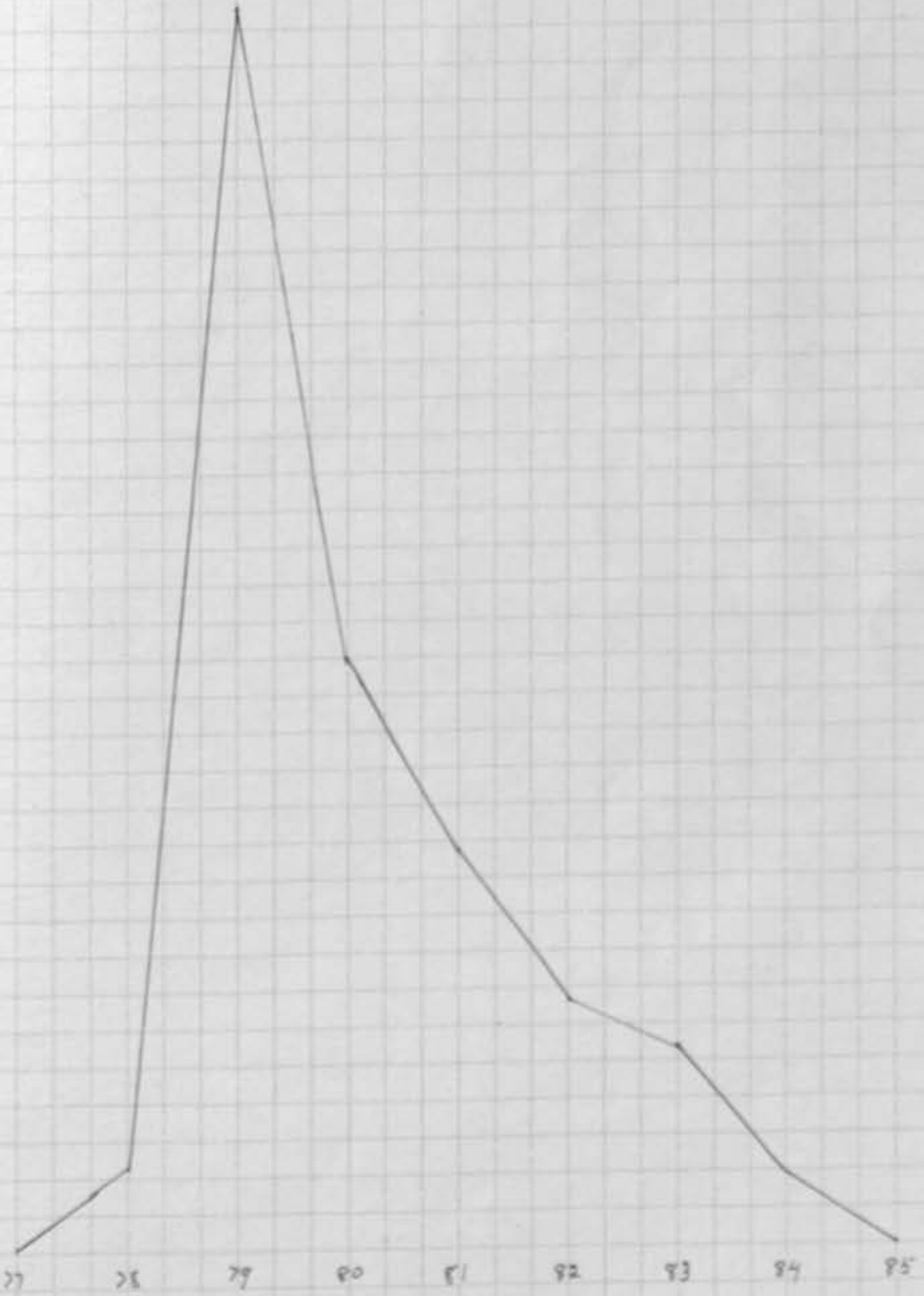


F1g. 7. - The Date of the Production of the Second, Third and Fourth Leaves, and the First Tlller, the Fmergence of the Awns, and the Day of Ripening, in Fourteen Selections of Barley Grown at St. Paul, Minn., in 1913. Bach Determination Based on One Centgener of Approximately One Hundred Plants. The leosacta numuals ar the number of the sebctions. 


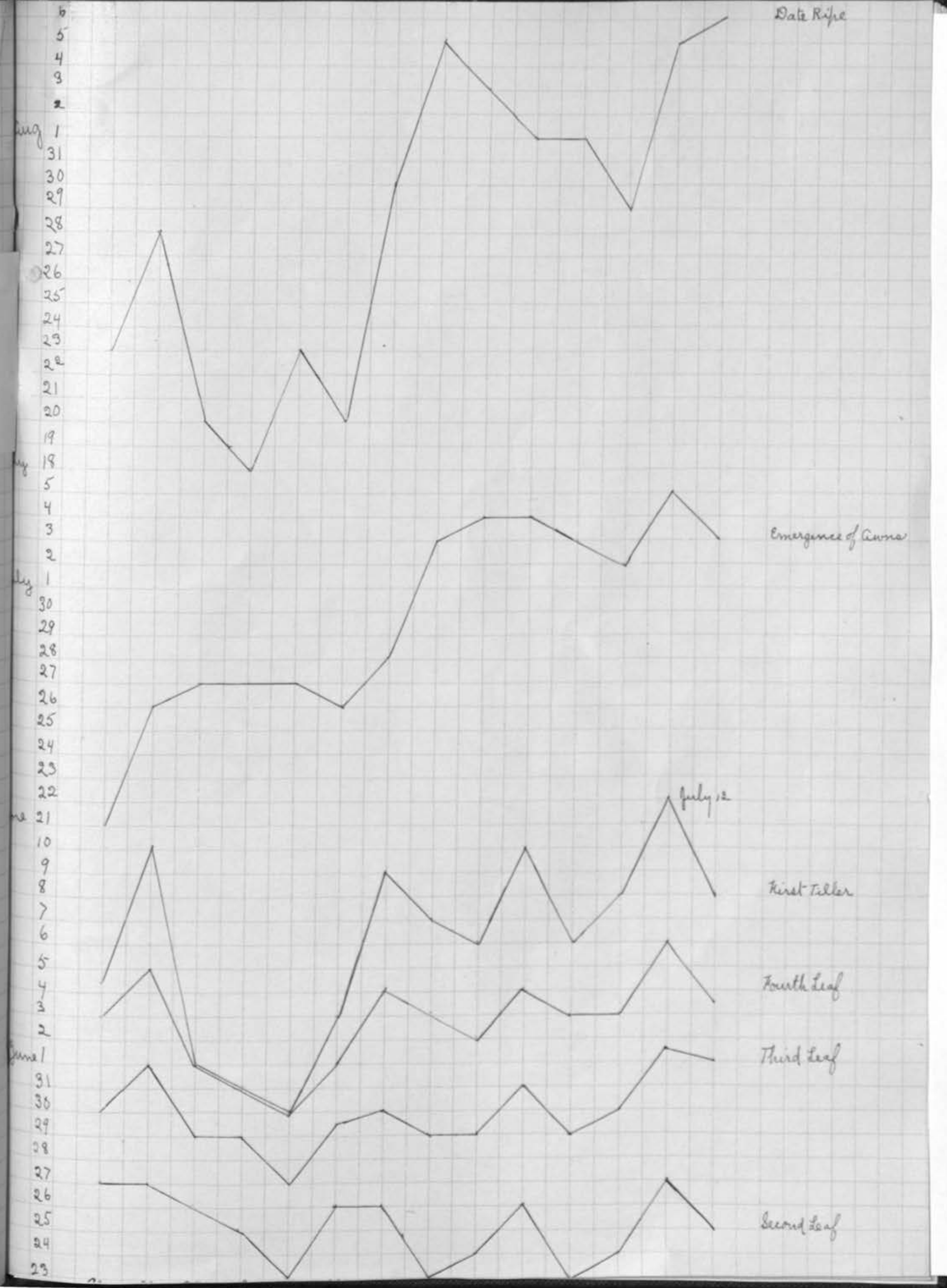


Fig. 8. - Composite Curves of the Width and Length of Leaves, the Upper ( $\mathbb{F}$ idth) in Millimeters, the Lower (Length) in Centimeters. The hrizatid numerals are measurements, the witical oned number of baves. 

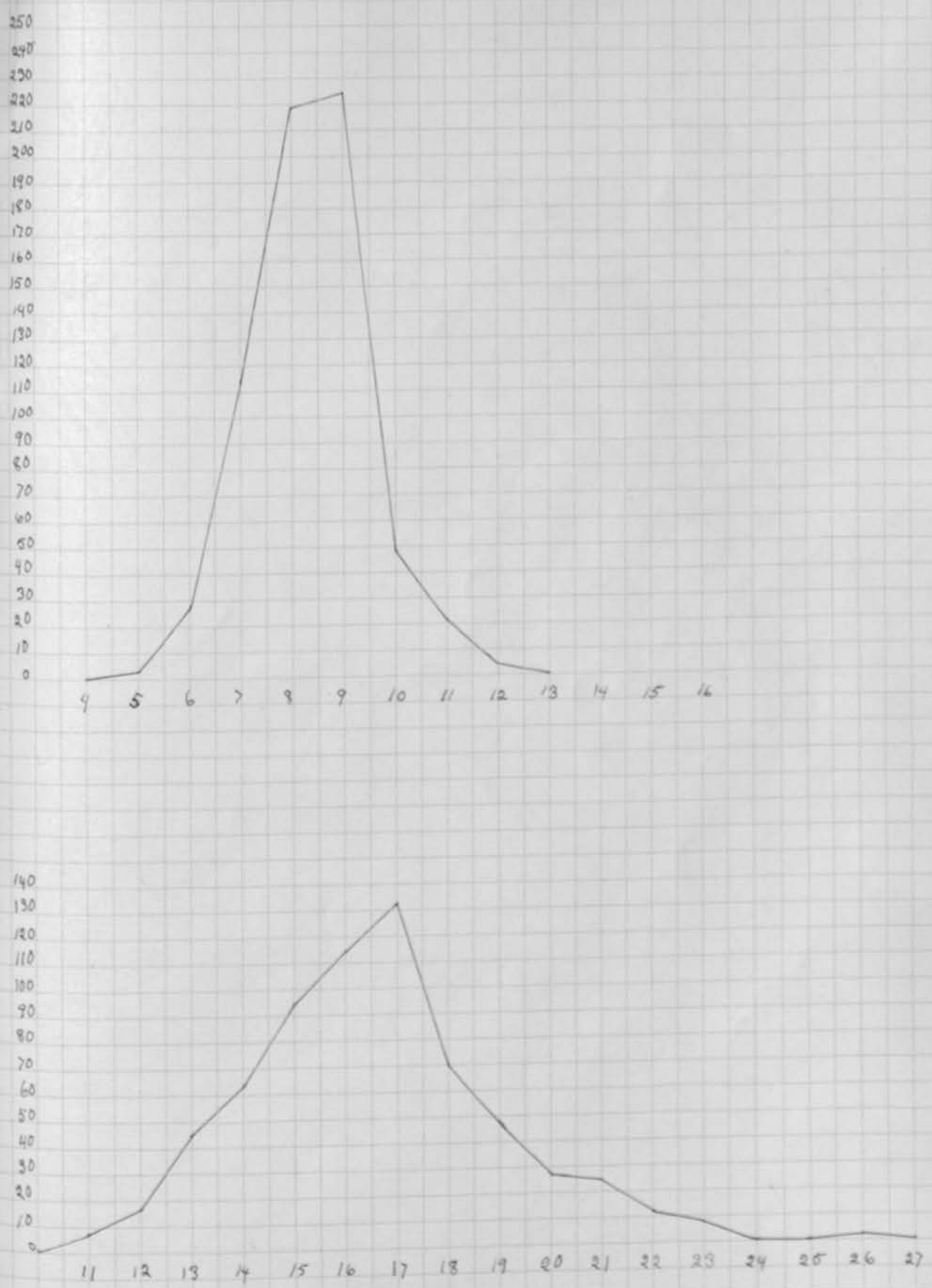
Fig. 9. - The Density of One Hundred Spikes of Manchuria Barley From a Field Near Bxcelsior, Minnesota. The herizidal 


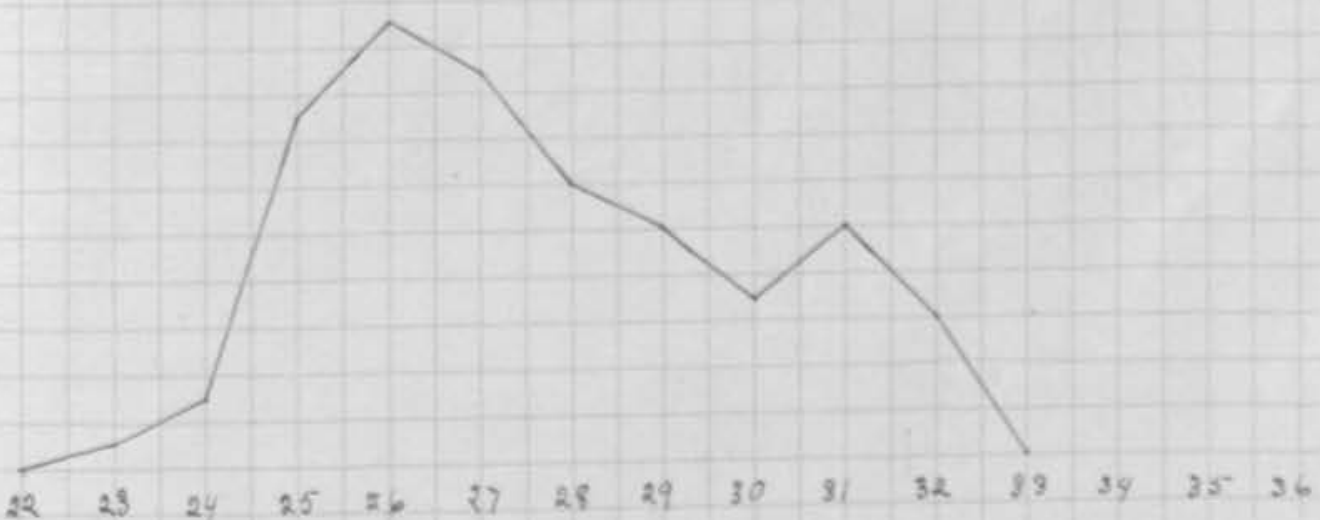


F1g. 10. - The Density of One Hundred Spikes From Each of Parts of the 1913 Nursory 35 , Planted in Different

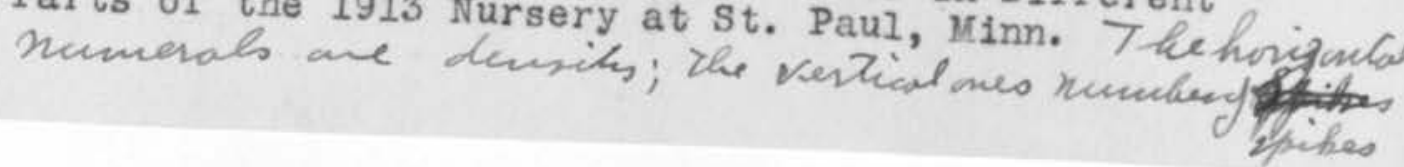




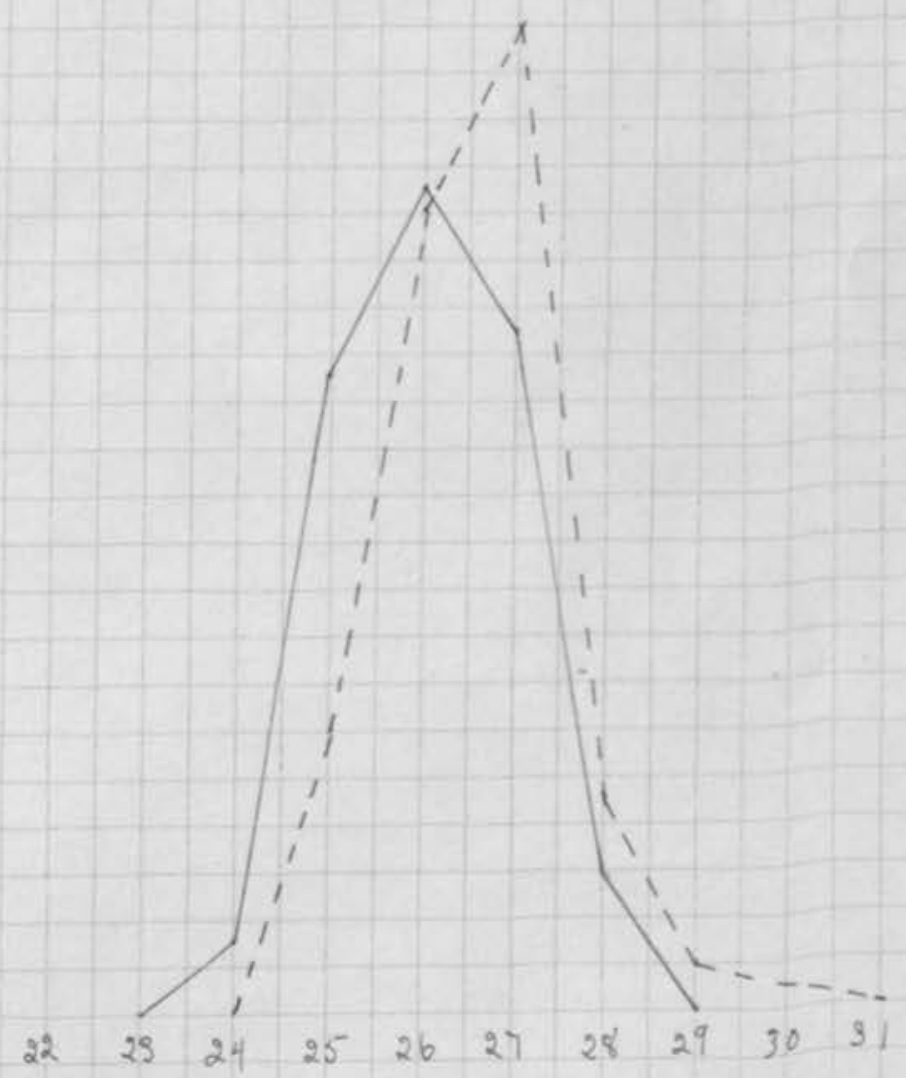


P1g. 11.- The Density of One Hundred Spikes in Bach of Two Selections of Manchuria Grown at St. Paul, in

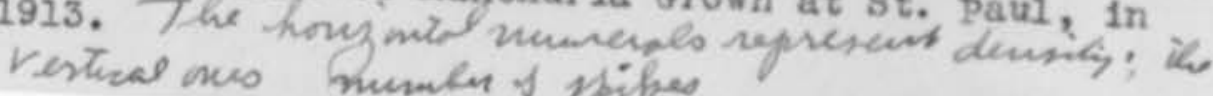




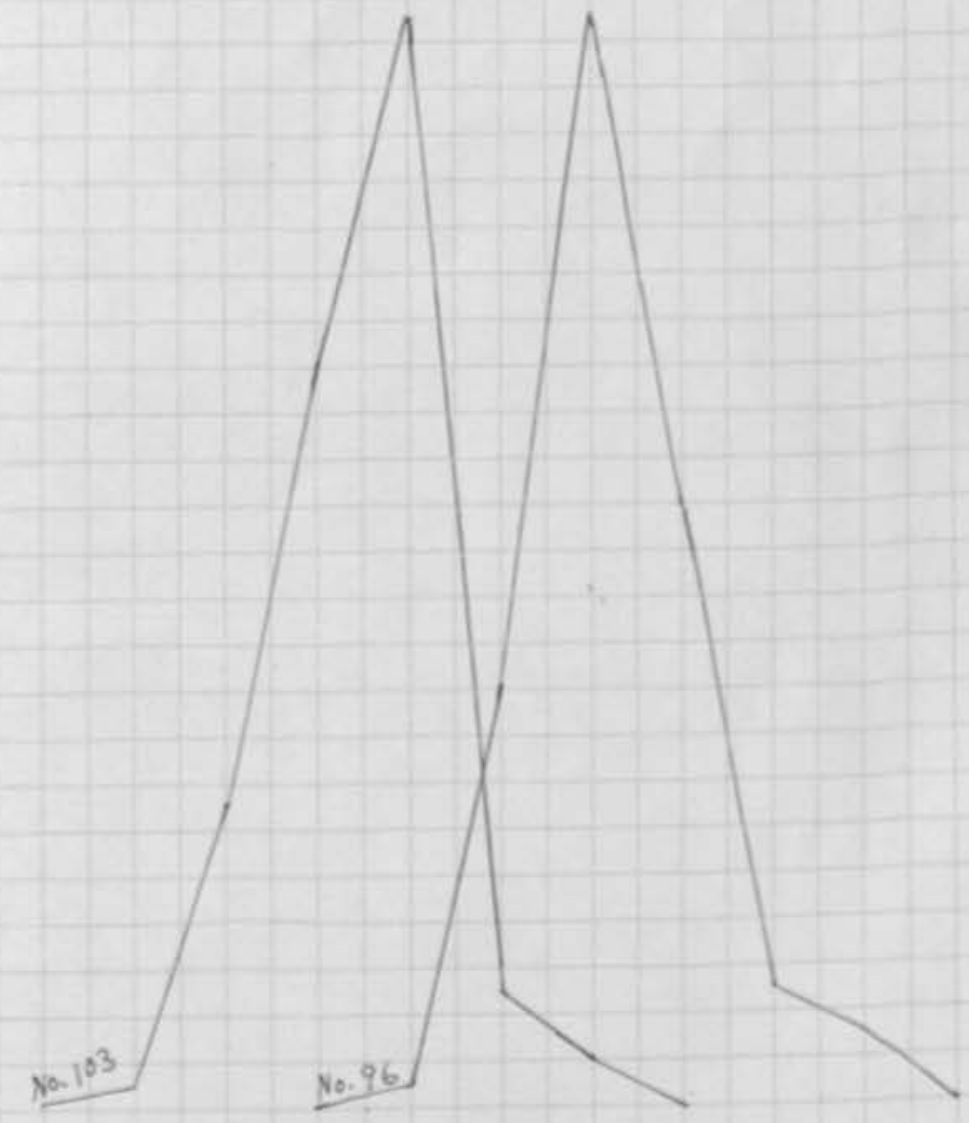

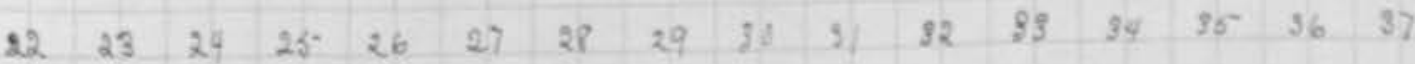




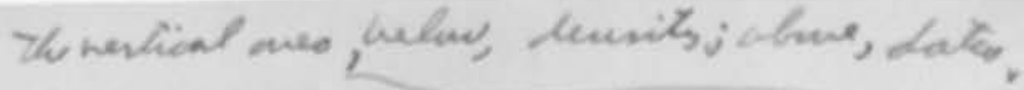

71g. 12.- The Average Density, and the Date of Energence of the Awns, in sixteen Selections of Yanchuris Barley Orown at St. Paul, Minn., in 1913. the honjuble nemerobs are the numbers of the selectios. 
F15. 13. - The Average Density, and the Date of the Fmergence of the Awns, In Twelve riscellaneous selectifons

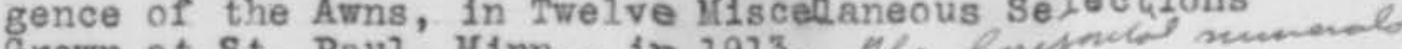

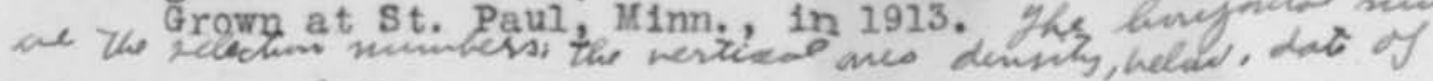
enungance above. 

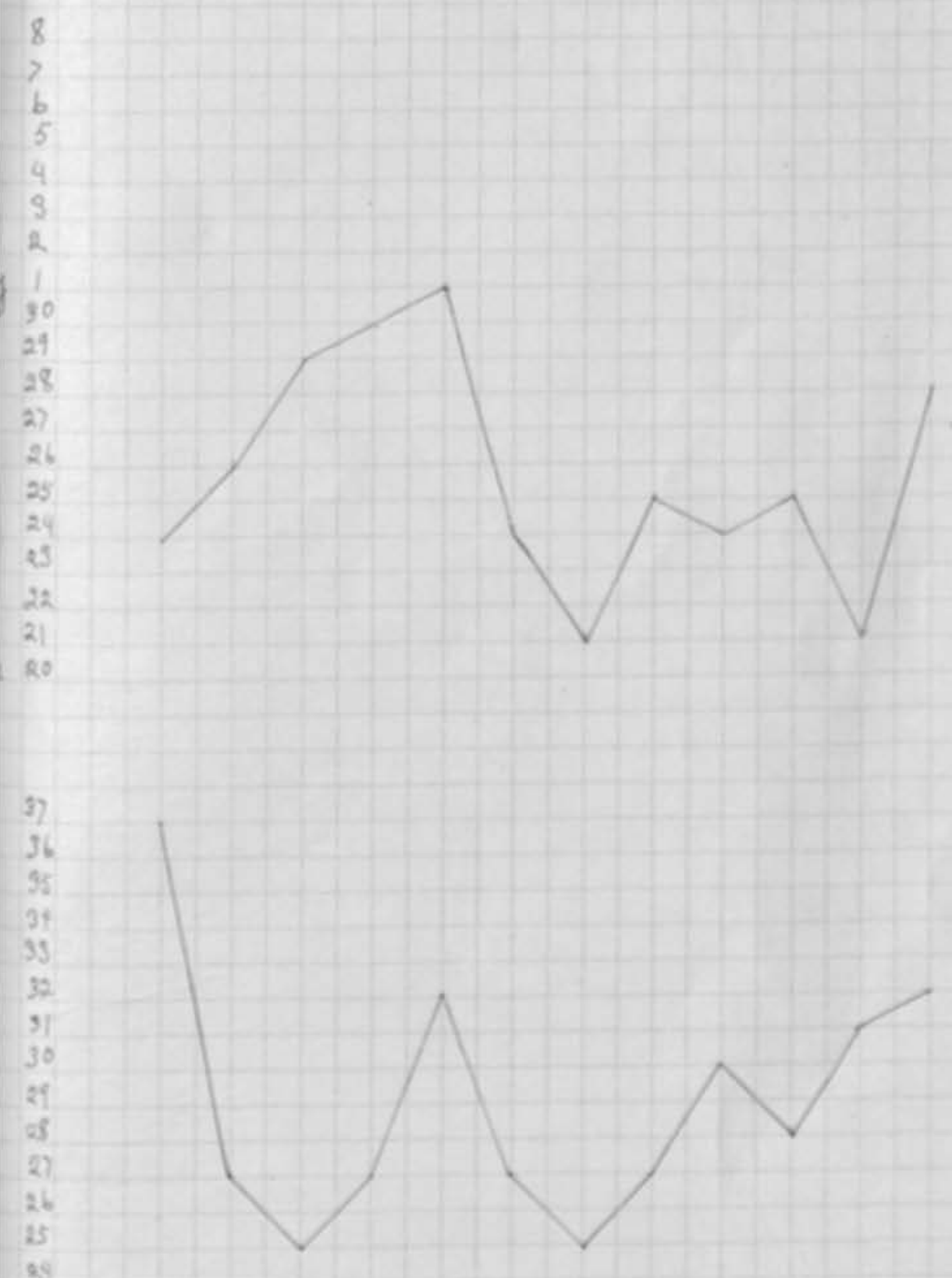

23
22
0

$\begin{array}{llllllllllll}7 & 94 & 97 & 21 & 93 & 35 & \text { ll } & 3 y & 12 & 95 & 52 & 9\end{array}$ 
F1g. 14.- The Density of 134 Spikes of Odessa, No. 9, Grown at St. paul, M1nn., in 1913. The thrizinis munuals

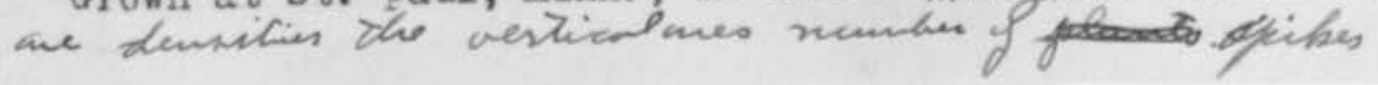



F1g. 15. - The Average Dens1ty of S1x Selections of Barley Grown at Chico, Cal1f., St. Paul, Minn., and at Aberdeen, Idaho. At the Latter Place Upon Both Irrigated and Unirrigated Land. 


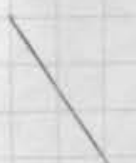

(

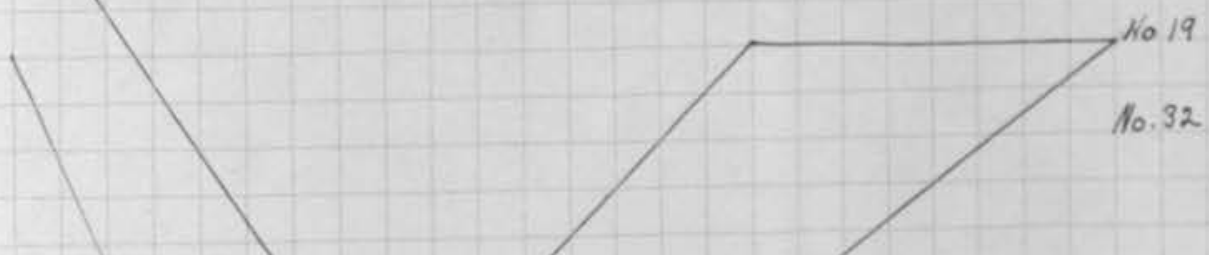

33

32
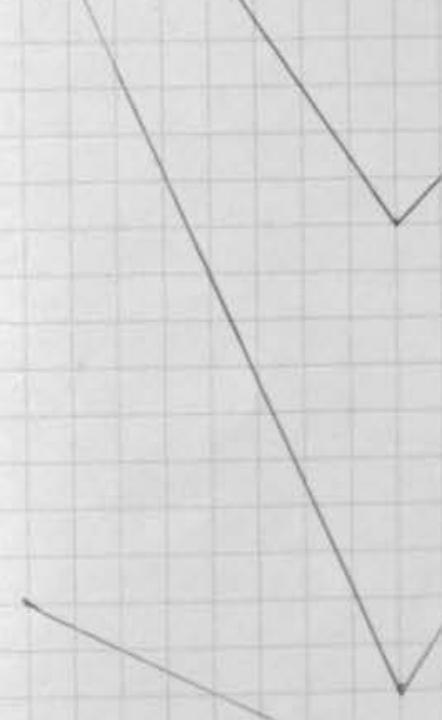

No. 13

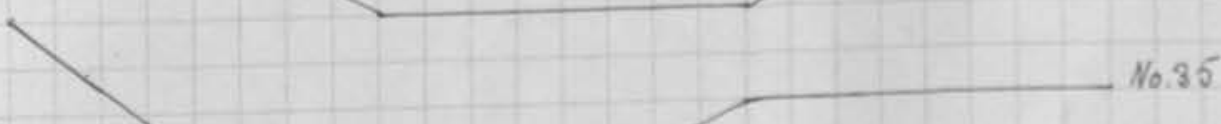

24

23

22

21

chico

stibar

Ariblem

Gindeen

shytand 
Harry Vaughn Harlan was born in London K11ls, Ill., February 19, 1882; attended the graded schools of Nalnut, Kans., from 1888 unt1I 1892 and of London Wills, Ill., from 1893 until 1896; received a high school education at Walnut, Kans., from 1896 unt1 1900, graduating in the latter year; attended the Agricultural College at Wanhattan, Kans., from 1901 to 1904 , receiving the degree of Bachelor of Science; entered the employ of the Philippine Government in 1905 as an agricultural instructor, remaining in this capacity until 1908; carried on studies in absentia for a Kaster's degree at the Kansas Agricultural College during 1906 and 1907, completing the work by one year's resident study in 1908 and 1909; entered the employ of the U. S. Department of Agriculture as an assistant in special barley investigationg; accepted full charge of the se studies in 1910 and of all barley investigations in 1912; began work leading to the degree of Doctor of Science in 1911, spending the greater part of the years 1911-19131and 1913 at the University of Minnesota; left the United States October, 1913, to undertake a $81 x$-months' study of the Peruvian Andes. 